\title{
Eph Receptor Signaling and Ephrins
}

\author{
Erika M. Lisabeth ${ }^{1}$, Giulia Falivelli ${ }^{1,2}$, and Elena B. Pasquale ${ }^{1,3}$ \\ ${ }^{1}$ Cancer Center, Sanford-Burnham Medical Research Institute, La Jolla, California 92037 \\ ${ }^{2}$ Department of Pharmacology, University of Bologna, Bologna 40100, Italy \\ ${ }^{3}$ Department of Pathology, University of California San Diego, La Jolla, California 92093 \\ Correspondence: elenap@sanfordburnham.org
}

\begin{abstract}
The Eph receptors are the largest of the RTK families. Like other RTKs, they transduce signals from the cell exterior to the interior through ligand-induced activation of their kinase domain. However, the Eph receptors also have distinctive features. Instead of binding soluble ligands, they generally mediate contact-dependent cell-cell communication by interacting with surface-associated ligands-the ephrins-on neighboring cells. Eph receptor-ephrin complexes emanate bidirectional signals that affect both receptor- and ephrin-expressing cells. Intriguingly, ephrins can also attenuate signaling by Eph receptors coexpressed in the same cell. Additionally, Eph receptors can modulate cell behavior independently of ephrin binding and kinase activity. The Eph/ephrin system regulates many developmental processes and adult tissue homeostasis. Its abnormal function has been implicated in various diseases, including cancer. Thus, Eph receptors represent promising therapeutic targets. However, more research is needed to better understand the many aspects of their complex biology that remain mysterious.
\end{abstract}

The he Eph receptors have the prototypical RTK topology, with a multidomain extracellular region that includes the ephrin ligand-binding domain, a single transmembrane segment, and a cytoplasmic region that contains the kinase domain (Fig. 1). There are nine EphA receptors in the human genome, which promiscuously bind five ephrin-A ligands and five EphB receptors, which promiscuously bind three ephrinB ligands (Pasquale 2004, 2005). Additionally, EphA4 and EphB2 can also bind ephrins of a different class. Two members of the family, EphA10 and EphB6, have modifications in conserved regions of their kinase domains that pre- vent kinase activity. Furthermore, a variety of alternatively spliced forms identified for many Eph receptors differ from the prototypical structure and have distinctive functions (Zisch and Pasquale 1997; Pasquale 2010).

Both ephrin classes include a conserved Eph receptor-binding domain, which is connected to the plasma membrane by a linker segment whose length can be affected by alternative splicing (Fig. 1). The ephrin-As are attached to the cell surface by a glycosylphosphatidylinositol (GPI) anchor, although they can also be released to activate EphA receptors at a distance (Bartley et al. 1994; Wykosky et al. 2008), whereas the

Editors: Joseph Schlessinger and Mark A. Lemmon

Additional Perspectives on Signaling by Receptor Tyrosine Kinases available at www.cshperspectives.org

Copyright (C) 2013 Cold Spring Harbor Laboratory Press; all rights reserved; doi: 10.1101/cshperspect.a009159

Cite this article as Cold Spring Harb Perspect Biol 2013;5:a009159 
E.M. Lisabeth et al.

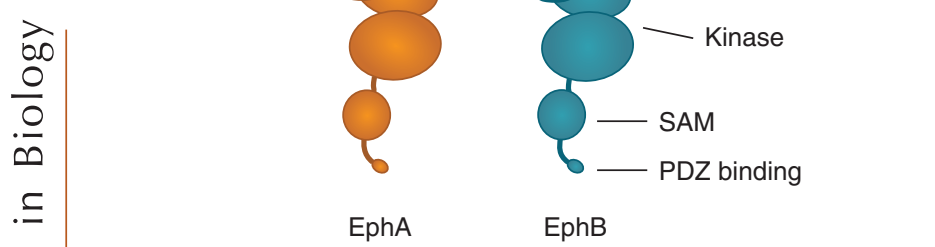

Figure 1. Domain structure of Eph receptors and ephrins.

ephrin-Bs contain a transmembrane segment and a short cytoplasmic region. Ephrin-A3 and ephrin-B3 also bind heparan sulfate proteoglycans through an interaction that involves their extracellular linker region and that, at least in the case of ephrin-A3, potentiates EphA receptor activation and signaling (Irie et al. 2008; Holen et al. 2011).

The Eph receptor family has greatly expanded during evolution, and includes almost one fourth of the 58 human RTKs (Schlessinger and Lemmon 2013). A large number of Eph receptors and ephrins may be required to achieve and maintain the sophisticated tissue organization of higher organisms. Indeed, many are highly expressed in the most complex organ, the brain, particularly during the establishment of its complex architecture and intricate wiring of neuronal connections (Yamaguchi and Pasquale 2004). Besides the brain, Eph receptors and ephrins are also present in mostif not all-other tissues, often in a combinatorial manner and with dynamically changing expression patterns (Pasquale 2005). In some regions, Eph receptors and ephrins are both coexpressed in the same cells, in others they have mutually exclusive expression patterns or they can be expressed in complementary gradients. These situations likely reflect different signaling modalities with different biological outcomes.

Eph receptors and ephrins engage in a multitude of activities. They typically mediate contact-dependent communication between cells of the same or different types to control cell morphology, adhesion, movement, proliferation, survival, and differentiation (Pasquale 2005). Through these activities, during development, the Eph/ephrin system plays a role in the spatial organization of different cell populations, axon guidance, formation of synaptic connections between neurons, and blood vessel remodeling. In the adult, the Eph/ephrin system regulates remodeling of synapses, epithelial differentiation and integrity, bone remodeling, immune function, insulin secretion, and stem cell selfrenewal (Pasquale 2008; Genander and Frisen 2010). In addition, Eph receptors and ephrins are often up-regulated in injured tissues, where they inhibit some regenerative processes but promote angiogenesis, as well as in cancer cells, where they seem to be able to both promote and suppress tumorigenicity (Du et al. 2007; Pasquale 2008, 2010).

Here we provide an overview of Eph receptor and ephrin signaling mechanisms and biological effects, with an emphasis on recent findings. More detailed information on specific aspects of Eph receptor/ephrin biology and downstream signaling networks can be found in other recent reviews (Pasquale 2005, 2008, 2010; Arvanitis and Davy 2008; Lackmann and Boyd 2008; Klein 2009; Genander and Frisen 2010).

\section{EPH RECEPTOR FORWARD SIGNALING}

"Forward" signaling corresponds to the prototypical RTK mode of signaling, which is triggered by ligand binding and involves activation of the kinase domain. However, the activation mechanisms of Eph receptors have unique features as compared to other RTK families (Barton et al. 2013). Binding between Eph receptors and ephrins on juxtaposed cell surfaces leads to oligomerization through not only Eph receptor-ephrin interfaces but also receptor-receptor cis interfaces located in multiple domains 
Eph Receptor Signaling and Ephrins

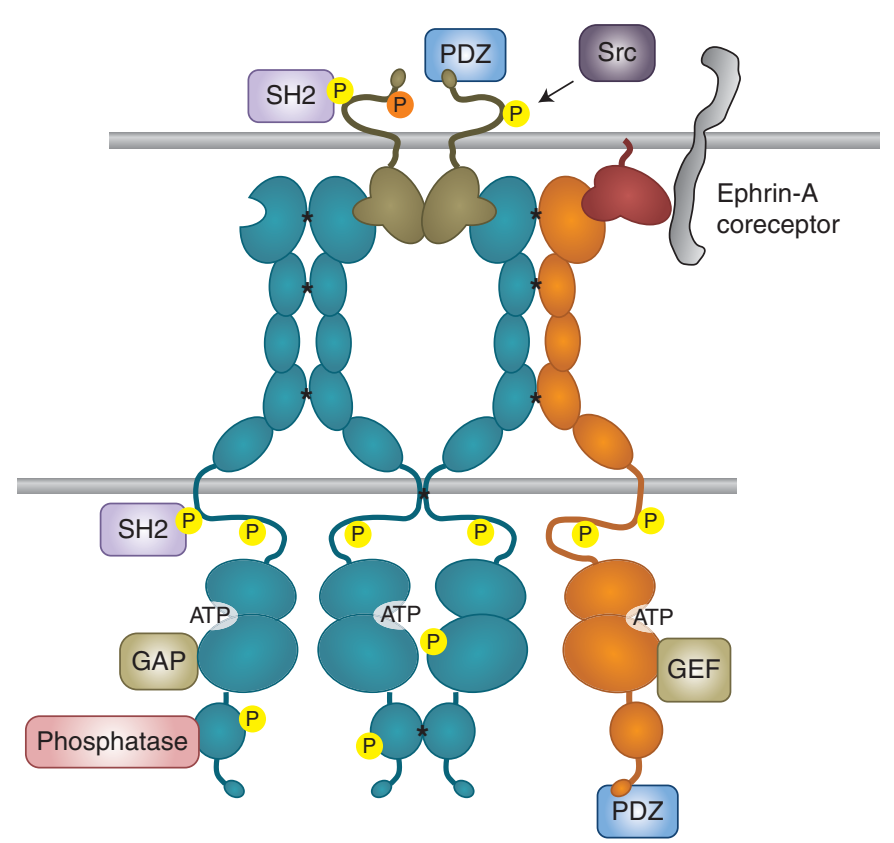

Figure 2. Eph receptor clustering and bidirectional signaling. SH2 and PDZ indicate proteins containing these domains. All types of signaling proteins shown can associate with both EphA and EphB receptors. Asterisks indicate receptor-receptor interactions favoring clustering; yellow circles indicate tyrosine phosphorylation and the orange circle indicates serine phosphorylation.

(Fig. 2) (Himanen et al. 2010; Seiradake et al. 2010). In fact, Eph receptor clusters induced by ephrin binding can enlarge to incorporate Eph receptors that are not bound to ephrins (Wimmer-Kleikamp et al. 2004). The cellular context can also affect Eph receptor clustering ability, which depends on association with the actin cytoskeleton (Salaita and Groves 2010). Given the promiscuity of Eph receptor-ephrin interactions, and also receptor-receptor cis interactions, the clusters can include Eph receptors of both A and B classes (Janes et al. 2011).

The proximity of clustered Eph receptor molecules leads to trans-phosphorylation. Phosphorylation of two conserved tyrosines in the juxtamembrane domain relieves inhibitory intramolecular interactions with the kinase domain, enabling efficient kinase activity (Binns et al. 2000; Zisch et al. 2000; Wybenga-Groot et al. 2001). Phosphorylation of the conserved tyrosine in the activation loop appears to be less critical for Eph receptor activation than it is for many other RTKs, although it may be important for maximal activity (Binns et al. 2000; Singla et al. 2011). There are also differences in the kinase domains within the Eph receptor family. For example, the "gatekeeper" residue in the hinge region between the kinase domain lobes, which controls access to a hydrophobic pocket adjacent to the ATP-binding site, is a threonine in most Eph receptors but a valine in EphA6 and an isoleucine in EphA7. Hence, EphA6 and EphA7 likely differ from the other Eph receptors in their sensitivity to kinase inhibitors and possibly substrate specificity (Skaggs et al. 2006; Zhang et al. 2009a).

The Eph receptors modulate many of the same networks of adaptor and effector proteins that also function downstream of other RTK families (Wagner et al. 2013). Various tyrosine autophosphorylation sites in activated Eph receptors-including the two regulatory juxtamembrane sites-enable recruitment of downstream signaling proteins that contain $\mathrm{SH} 2$ domains, including nonreceptor tyrosine kinases of the Src and Abl families and adaptors such 
E.M. Lisabeth et al.

as Nck and Crk, which are crucial for signal transduction (Fig. 2) (Jorgensen et al. 2009; Pasquale 2010). Binding of PDZ domain-containing proteins to the carboxy-terminal tails of Eph receptors also contributes to signaling. Particularly important effectors are Rho and Ras family GTPases and Akt/mTORC1. Interestingly, whereas most other RTK families use these central regulators of cellular physiology to stimulate cell proliferation, survival, and forward movement, the Eph receptors can use them to inhibit cell growth and achieve cell repulsion. In cancer cells, this can result in tumor suppression.

Signaling by the Eph receptors, however, is not always consistent and can lead to divergent outcomes. The kinase-inactive Eph receptors and alternatively spliced forms lacking the kinase domain can modulate signaling outcome by reducing signal strength in the clusters as well as by contributing distinctive signals. For example, the kinase inactive EphB6 can be phosphorylated by other Eph receptors and subvert the effects of EphB4 in breast cancer cells (Truitt and Freywald 2011). Moreover, a truncated membrane-anchored form of the EphA7 extracellular domain can convert repulsion to cell-cell adhesion in the developing neural tube by decreasing signaling by full-length EphA7 (Holmberg et al. 2000), and a secreted truncated form of EphA7 acts as a tumor suppressor in follicular lymphoma by binding EphA2 and blocking its oncogenic signals (Oricchio et al. 2011). There is also evidence that small and large Eph receptor clusters differ in their ability to recruit certain signaling molecules (Salaita and Groves 2010). Other aspects of the cellular context, and implementation of positive and negative feedback loops, further contribute to the diversity of Eph receptor activities.

\section{Rho Family GTPases}

The Eph receptors are well known for their effects on the actin cytoskeleton, which impact cell shape, adhesion, and movement through regulation of the Rho GTPase family, including RhoA, Rac1, and Cdc42 (Pasquale 2008, 2010). GTPases cycle between a GDP bound (inactive) state and a GTP bound (active) state that binds downstream effectors. The Eph receptors can influence these conversions by regulating both guanine nucleotide exchange factors (GEFs, which facilitate GDP to GTP exchange) and GTPase-activating proteins (GAPs, which promote GTP hydrolysis to GDP). Regulation of GEFs and GAPs by Eph receptors can involve constitutive or ephrin-induced association, tyrosine phosphorylation, or even ubiquitination and degradation.

RhoA is mostly involved in the formation of stress fibers and focal adhesions as well as contraction of the actomyosin cytoskeleton, whereas Rac1 and Cdc42 drive the formation of protrusive structures such as lamellipodia and filopodia, respectively (Heasman and Ridley 2008). An increased balance of RhoA versus Rac1/Cdc42 activities has been implicated in the characteristic repulsive effects of Eph receptor forward signaling, including process retraction and inhibition of cell migration/invasiveness (Fig. 3A-C). The collapse or local retraction of neuronal growth cones and dendritic spines (the small protrusions on dendrites bearing excitatory synapses) are well-known repulsive effects of EphA receptors that depend on Rho family GTPases (Fig. 3B,C) (Wahl et al. 2000; Murai et al. 2003; $\mathrm{Fu}$ et al. 2007). Growth cone collapse involves RhoA activation, for example, by the GEF Ephexin1 (Shamah et al. 2001; Sahin et al. 2005), and Rac1 inactivation, for example, by the GAP $\alpha 2$-Chimaerin (Beg et al. 2007; Iwasato et al. 2007; Shi et al. 2007; Wegmeyer et al. 2007). However Rac1 activation, which can occur downstream of Vav family GEFs, is also required for growth cone collapse and to process retraction by enabling endocytic removal of adhesive Eph receptor-ephrin complexes from sites of cell-cell contact (Cowan et al. 2005; Yoo et al. 2011). Activation and inactivation of Rho family GTPases may occur with different spatial and/or temporal resolution to achieve growth cone collapse and regulate dendritic spines. In other cell types, Eph repulsive signaling involving Rho family GTPases can lead to mesodermal-ectodermal tissue separation during gastrulation (Park et al. 2011; Rohani et al. 2011), Schwann cell-astrocyte segregation in the in- 
A Cell-cell repulsion (with trans-endocytosis)

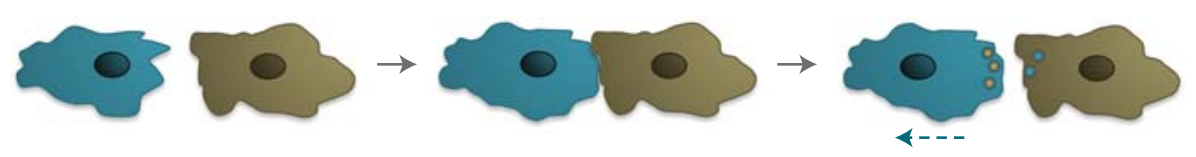

B Growth cone collapse (with ephrin cleavage)

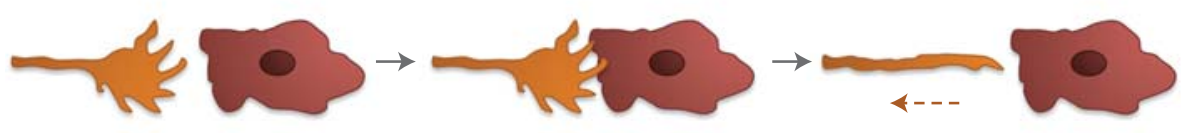

C Dendritic spine retraction (following contact with glial process)

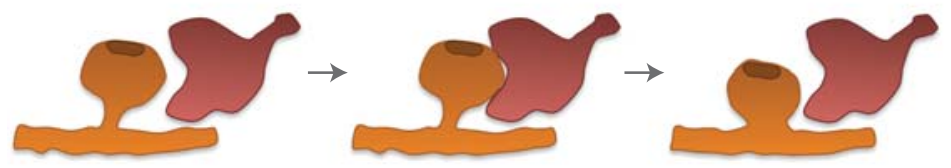

D Dendritic spine maturation (following dendritic filopodium contact with axon)

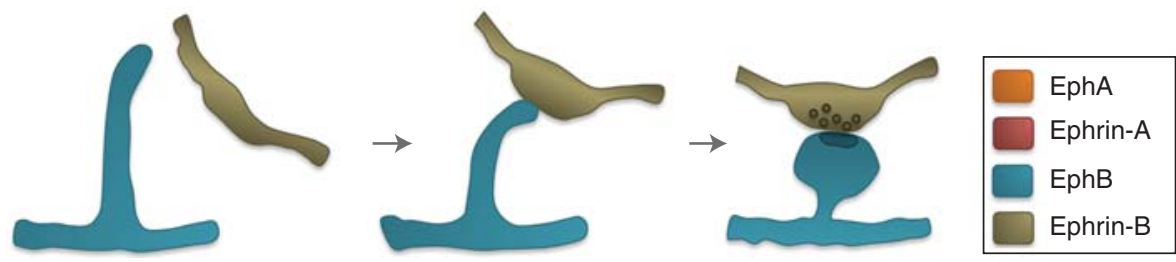

Figure 3. Eph receptor-ephrin repulsive effects and dendritic spine maturation. (A) An EphB-expressing cell encounters an ephrin-B-expressing cell and retracts after the internalization of EphB-ephrin-B complexes enables cell separation. $(B)$ An EphA-expressing growth cone at the leading edge of an axon encounters an ephrin-A-expressing cell, collapses, and begins to retract after the cleavage of ephrin-A molecules enables cell separation. ( $C$ ) An EphA-expressing spine on a dendrite (bearing an excitatory postsynaptic terminal represented as a darker oval) comes in contact with an ephrin-A-expressing glial process and retracts becoming shorter. $(D)$ An EphB-expressing filopodial protrusion on a dendrite acquires an enlarged "head" and shortens following contact with an ephrin-B-expressing axon. The presynaptic terminal also matures following contact.

jured nervous system (Afshari et al. 2010), and contact inhibition of locomotion (Astin et al. 2010).

Regulation of Rho family GTPases by Eph receptors can also control cellular processes beyond repulsion. For example, the maturation of neuronal filopodial protrusions into dendritic spines (Fig. 3D) entails ephrin-B/EphB-dependent activation of the Rac-GEFs Kalirin and Tiam1 and the Cdc42-GEF Intersectin to promote the formation of branched actin filaments that enlarge the distal portion of the filopodial protrusions (Irie and Yamaguchi 2002; Penzes et al. 2003; Tolias et al. 2007), whereas RhoA activation through focal adhesion kinase and a RhoGEF shortens the protrusions (Moeller et al. 2006). Interestingly, EphB receptor forward signaling can also promote synapse formation through ubiquitination and degradation of the Rho-GEF Ephexin5, which decreases RhoA activity without obvious effects on spine morphology (Margolis et al. 2010). Furthermore, EphA2 forward signaling can promote endothelial angiogenic responses by activating Racl through Vav family GEFs (Hunter et al. 2006) and enhance epithelial characteristics by inhibiting RhoA through p190RhoGAP (Wakayama et al. 2011). In addition, EphB receptor activation by ephrin-B-expressing stromal cells promotes HGF-dependent invasiveness of metastatic PC3 prostate cancer cells through sustained Cdc42 activation (Astin et al. 2010). 
E.M. Lisabeth et al.

Further work is needed to understand in detail the mechanisms leading to activation versus inhibition of Rho GTPases by Eph receptors and examine the role of the many less well-characterized Rho family members in the biological activities of Eph receptors.

\section{Ras Family GTPases}

Perhaps the most prototypical RTK signaling pathway involves activation of the $\mathrm{H}$-Ras GTPase by the GEF Sos, which is recruited by the adaptors Shc and/or Grb2 bound to activated RTKs (McKay and Morrison 2007). H-RasGTP triggers a phosphorylation cascade that culminates in activation of the Erk1 and Erk2 serine/threonine kinases. Through phosphorylation of cytoplasmic effectors and nuclear transcription factors, the Ras-Erk pathway regulates many physiological processes-including cell proliferation, survival, differentiation, adhesion, and migration - and its deregulation can cause cancer and other diseases.

Remarkably, Eph receptor forward signaling frequently inhibits the Ras-Erk pathway and can override its activation by other RTKs (Pasquale 2008, 2010). For example, polarized Eph receptor activation in progenitor cells of the ascidian embryo attenuates Erk activation by the FGF RTK, leading to asymmetric division and fate specification (Picco et al. 2007; Shi and Levine 2008). Furthermore, ephrin-A/EphA signaling induced by contact between myoblasts suppresses Erk activation by the IGF-1 RTK, facilitating myogenic differentiation (Minami et al. 2011). In neurons, EphA-dependent Erk inhibition suppresses the effects of the TrkB RTK on growth cone motility and gene expression (Meier et al. 2011) and promotes growth cone collapse (Nie et al. 2010). In cancer cells, ephrin-A/EphA signals that suppress Erk activation by RTKs can inhibit tumorigenicity (Miao et al. 2001; Macrae et al. 2005).

A common mechanism of Eph receptordependent Erk inhibition is through p120RasGAP, which inactivates H-Ras (Elowe et al. 2001; Minami et al. 2011). Through p120RasGAP, the Eph receptors can also inhibit another Ras family GTPase, R-Ras, causing the reduced integrin activity that is important for retraction of cell processes and decreased malignancy (Dail et al. 2006). Eph receptors can also negatively regulate Rap1, another member of the Ras family involved in integrin activation, by inhibiting the GEF C3G or activating the GAP SPAR (Riedl et al. 2005; Richter et al. 2007; Huang et al. 2008; Pasquale 2008).

In some cases, however, Eph receptors behave similarly to other RTKs and activate the Ras-Erk pathway. For example, in cultured mouse mesenchymal cells, ephrin-B1-EphB signaling activates Erk to promote proliferation and regulate immediate early gene transcription (Bush and Soriano 2010). In P19 embryonal carcinoma cells and microvascular endothelial cells, ephrin-stimulated EphB1 recruits the adaptors Shc and Grb2 to activate H-Ras and increase cell migration (Vindis et al. 2003). Interestingly, the activation of EphB4 by ephrinB2 in MCF7 breast cancer cells promotes Erk1/ 2 activation through an unusual pathway that seems to require the PP2A serine/threonine phosphatase (Xiao et al. 2012). In stably transfected HEK293 cells, EphB2 forward signaling activates Erk to promote cell repulsion (Poliakov et al. 2008). The interplay between Eph receptors and Ras GTPases also involves feedback loops in which Ras-Erk signaling reciprocally influences Eph receptors, for example, by reinforcing ephrin-B1/EphB2 signaling or up-regulating EphA2 gene transcription (Menges and McCance 2008; Poliakov et al. 2008).

\section{Akt}

Akt is a serine/threonine kinase that regulates cell size, proliferation, and survival through various downstream effectors such as mTOR complex 1 (mTORC1). RTKs typically activate Akt through PI3 kinase, a lipid kinase that initiates a pathway leading to Akt activation through phosphorylation on T308 and S473 (Manning and Cantley 2007). In contrast, Eph receptor forward signaling can suppress Akt activation. For instance, in a variety of cancer cells, ephrindependent EphA2 activation leads to rapid dephosphorylation of Akt T308 and S473, which likely depends on regulation of a phosphatase, 
Eph Receptor Signaling and Ephrins

leading to mTORC1 inactivation and decreased cell growth and migration (Menges and McCance 2008; Miao et al. 2009; Yang et al. 2011). Remarkably, this can occur even in cancer cells where the PI3 kinase-Akt pathway is activated by oncogenic mutations. EphB3 kinase activation can also inhibit Akt, which leads to suppression of non-small-cell lung cancer migration and metastasis, by promoting the assembly of a complex involving the EphB3-binding partner RACK1 (receptor for activated C-kinase 1), the serine/threonine phosphatase PP2A and Akt itself (Li et al. 2012). However, Eph receptors can also activate Akt, for example, in pancreatic cancer cells stimulated with ephrin-A1 (Chang et al. 2008) or in malignant T lymphocytes where ephrin-B treatment suppresses apoptosis (Maddigan et al. 2011).

Akt signaling can reciprocally influence Eph receptors through feedback loops. For example, phospho-RTK arrays suggest an up-regulation of several tyrosine-phosphorylated Eph receptors in cancer cells treated with Akt inhibitors (Chandarlapaty et al. 2011). Furthermore, Akt can phosphorylate EphA2 on S897 drastically altering receptor function (see below), whereas ephrin-A1 stimulation causes loss of S897 phosphorylation (Miao et al. 2009).

\section{EPHRIN REVERSE SIGNALING}

Besides forward signaling, the Eph receptors can also stimulate "reverse" signaling in the ephrinexpressing cells (Fig. 2) (Pasquale 2005, 2010). A central feature enabling signaling by the ephrins, which lack an enzymatic domain, is the activation of Src family kinases. Eph receptor binding causes ephrin-B phosphorylation by Src kinases, creating binding sites for the SH2 domains of signaling proteins such as the adaptor Grb4 (Cowan and Henkemeyer 2001; Palmer et al. 2002). Ephrin-B signaling through Grb4 controls axon pruning, synapse formation and dendritic spine morphogenesis in the developing mouse hippocampus (Segura et al. 2007; $\mathrm{Xu}$ and Henkemeyer 2009). Phosphorylation of a serine near the ephrin-B carboxyl terminus, which is also induced by EphB receptor binding, leads to stabilization of AMPA neurotransmit- ter receptors at synapses (Essmann et al. 2008). This might regulate synaptic plasticity in concert with ephrin-B tyrosine phosphorylation (Bouzioukh et al. 2007).

Recruitment of signaling proteins containing PDZ domains to the ephrin-B carboxyl terminus is also crucial for reverse signaling. For example, the adaptor PDZ-RGS3 connects ephrin-B to G-protein-coupled receptors that control neuronal cell migration and neural progenitor self-renewal (Lu et al. 2001; Qiu et al. 2010). Ephrin-B interaction with PDZ domain proteins also promotes angiogenesis and lymphangiogensis by enabling VEGF receptor endocytosis, and can regulate axon guidance and synaptic plasticity (Makinen et al. 2005; Bouzioukh et al. 2007; Bush and Soriano 2009; Sawamiphak et al. 2010; Wang et al. 2010). Furthermore, ephrin-B signaling controls neuronal migration in the developing mouse brain through cross talk with the secreted glycoprotein Reelin (Senturk et al. 2011), modulates epithelial cell-cell junctions through the Par polarity complex (Lee et al. 2008), disrupts gap junctional communication (Mellitzer et al. 1999; Davy et al. 2006), and enhances glioma cell invasiveness by activating Rac1 (Nakada et al. 2006).

The ephrin-As lack a cytoplasmic domain and it is not well understood how they activate intracellular signaling. Studies in neurons have implicated the p75 neurotrophin receptor and the TrkB and Ret RTKs as transmembranebinding partners that enable ephrin-A-dependent reverse signals involved in axon guidance and branching (Fig. 2) (Lim et al. 2008; Marler et al. 2008, 2010; Bonanomi et al. 2012). Through these and likely other binding partners, the ephrin-As have diverse signaling activities. Ephrin-A2 reverse signaling can inhibit neural progenitor cell proliferation, perhaps opposing the positive effects of ephrin-B1 (Holmberg et al. 2005). In the adult hippocampus, glial ephrin-A3 functions together with neuronal EphA4 to modulate uptake of the neurotransmitter glutamate by glial cells and, thus, synaptic plasticity (Carmona et al. 2009; Filosa et al. 2009). Ephrin-A4 can inhibit apoptotic cell death in Jurkat immune cells by activating Src family kinases and Akt (Holen et al. 2008). 
E.M. Lisabeth et al.

Ephrin-A5 reverse signaling in pancreatic $\beta$ cells can stimulate Racl activity, which is necessary for insulin secretion after glucose stimulation (Konstantinova et al. 2007). Ephrin-A5 can also increase cell-substrate adhesion in fibroblasts and astrocytes by activating the Src family kinase Fyn and integrins, and seems able to also promote invasiveness (Davy et al. 1999, 2000; Campbell et al. 2006). Furthermore, this ephrin promotes Fyn activation in glioma and HEK293 cells, leading to Cbl-dependent EGF RTK ubiquitination and degradation ( $\mathrm{Li}$ et al. 2009). Interestingly, Fyn can in turn function in a negative feedback loop to down-regulate cell surface ephrin-A levels by modulating the metabolism of sphingomyelin (Baba et al. 2009).

\section{BEYOND BIDIRECTIONAL SIGNALING}

\section{Internalization and Proteolytic Cleavage}

Following ligand-dependent activation, RTKs are typically internalized by endocytosis and can continue to signal from intracellular compartments until they are inactivated by dephosphorylation and degradation or traffic back to the cell surface (Goh and Sorkin 2013). For the Eph receptors, this process has unique features as a result of the plasma membrane association of the ephrins (Marston et al. 2003; Zimmer et al. 2003; Pitulescu and Adams 2010). Eph receptor-ephrin complexes can be internalized into either the Eph receptor- or the ephrin-expressing cells through the formation of vesicles containing plasma membrane fragments derived from both cells (Fig. 3A). This Rac1-dependent process, which has been defined "transendocytosis," is critical for removal of adhesive complexes from cell-cell contact sites to allow cell separation and repulsive effects. Another protein that contributes to Eph receptor internalization and degradation is the ubiquitin ligase Cbl, which can interact with several Eph receptors promoting their ubiquitination (Walker-Daniels et al. 2002; Fasen et al. 2008).

Besides trans-endocytosis, Eph receptorephrin complexes can convert adhesive interactions into cell repulsion by activating metalloproteases, such as ADAM family members. For example, the transmembrane ADAM10 protease can associate with ephrin-A2 on the same cell surface and cleave it following EphA receptor binding in trans to enable repulsive axon guidance (Hattori et al. 2000). ADAM10 can also associate with EphA3, whose active conformation promotes protease activity toward the ephrin in trans (Fig. 4A) (Janes et al. 2005, 2009). EphB receptors also interact with ADAM10, as well as the cell-adhesion molecule E-cadherin, and their binding to ephrin-Bs in trans provokes shedding of E-cadherin by ADAM10 preferentially in the ephrin-B-expressing cells (Fig. 4A) (Solanas et al. 2011). Cleavage by metalloproteases also plays a role in other Eph receptor/ ephrin activities. For example, ephrin-B cleavage by ADAM13 can terminate EphB/ephrin-B signals that inhibit canonical Wnt signaling in the Xenopus embryo, thus enabling cranial neural crest induction (Wei et al. 2010). Furthermore, ADAM19 functions independently of its protease activity to stabilize developing neuromuscular junctions by preventing internalization of the complexes between ephrin-A5 on the muscle and EphA4 on the innervating motor neuron (Yumoto et al. 2008).

Ephrin binding and other stimuli can also induce cleavage of the Eph receptor extracellular domain, followed by further intramembrane proteolytic processing via $\gamma$-secretase to generate cytoplasmic fragments capable of signaling (Litterst et al. 2007; Inoue et al. 2009; Xu et al. 2009). For example, calcium influx can induce combined metalloprotease $/ \boldsymbol{\gamma}$-secretase processing of both EphA4 and EphB2 (Litterst et al. 2007; Inoue et al. 2009). The released EphA4 cytoplasmic fragment increases dendritic spine numbers through kinase-independent Rac1 activation (Inoue et al. 2009). Instead, the EphB2 cytoplasmic fragment can phosphorylate NMDA neurotransmitter receptors, which promotes their cell surface localization and may lead to a positive feedback loop by increasing NMDA receptor-mediated calcium currents (Litterst et al. 2007; Xu et al. 2009). Interestingly, stress in mice can also cause cleavage of EphB2 by the extracellular serine protease neuropsin in the amygdala (Attwood et al. 2011). This cleavage results in EphB2 dissociation from the 
Eph Receptor Signaling and Ephrins
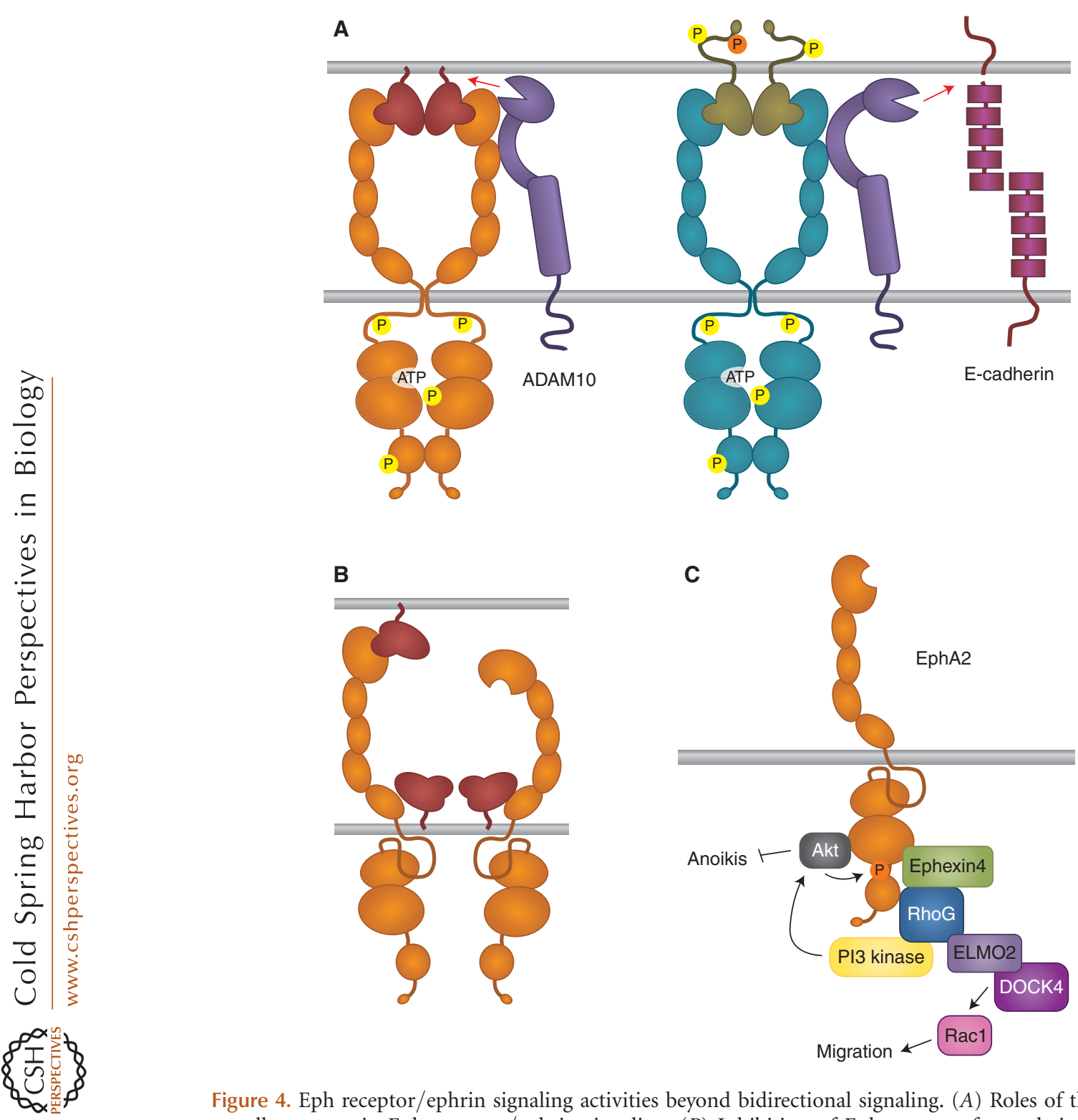

Figure 4. Eph receptor/ephrin signaling activities beyond bidirectional signaling. $(A)$ Roles of the ADAM10 metalloprotease in Eph receptor/ephrin signaling. $(B)$ Inhibition of Eph receptor forward signaling by cis interaction with ephrins. $(C)$ Ephrin-independent Eph receptor signaling.

NMDA receptor as well as enhances NMDA receptor ion currents and the behavioral signatures of anxiety. Whether this may also be a consequence of NMDA receptor phosphorylation by a proteolytically released EphB2 cytoplasmic fragment remains to be determined.

Ephrin-B ligands can also undergo metalloprotease $/ \boldsymbol{\gamma}$-secretase processing following binding to EphB receptors. The released ephrin-B2 cytoplasmic fragment can promote Src activation and Src-dependent phosphorylation of uncleaved ephrin-B2, which is important for reverse signaling (Georgakopoulos et al. 2006). This involves regulating the interplay between Src- and the Csk-binding protein $\mathrm{Cbp} / \mathrm{PAG}$, an adaptor that controls Src activity (Georgakopoulos et al. 2011). Moreover, ephrin-B1 cytoplasmic fragments present in the developing 
E.M. Lisabeth et al.

mouse brain can associate with the ZHX2 transcriptional repressor and enhance its activity in the nucleus to prevent neural progenitor differentiation (Wu et al. 2009).

Ephrin-Mediated Cis Attenuation of Eph Receptor Forward Signaling

Eph receptors and ephrins can be coexpressed in normal and cancer cells (Carvalho et al. 2006; Pasquale 2010; Kao and Kania 2011). In contrast to the autocrine signaling occurring when other RTKs and their soluble ligands are coexpressed (Zwick et al. 2002), a lateral cis interaction between Eph receptors and ephrins on the same cell surface can attenuate forward signaling (Fig. 4B) (Bohme et al. 1996; Yin et al. 2004). For example, EphA cis attenuation plays a role in topographic mapping of retinal axons (Hornberger et al. 1999; Carvalho et al. 2006) and ephrin-B3 inhibits signaling by EphB2 coexpressed in hippocampal synapses, decreasing tyrosine phosphorylation of NMDA neurotransmitter receptors (Antion et al. 2010). Ephrins also cause cis attenuation of EphA and EphB signaling in spinal cord motor neuron populations where they are highly expressed, which is important for proper axon guidance in the limb (Kao and Kania 2011). In contrast, in motor neuron populations where they are present at lower levels, ephrin-As segregate in different membrane microdomains than the coexpressed EphA receptors (Marquardt et al. 2005; Kao and Kania 2011). This segregation allows parallel activation of forward and reverse signaling in the same neurons. Biochemical and structural studies have implicated the second Eph receptor fibronectin type III domain in the cis interaction (Fig. 4B) (Carvalho et al. 2006; Seiradake et al. 2010). Consistent with this, an ephrin-A5 mutant that cannot engage the EphA ephrin-binding pocket was shown to still induce cis attenuation (Bohme et al. 1996; Carvalho et al. 2006; Kao and Kania 2011). However, how cis binding inhibits forward signaling remains unclear. Whereas a mechanism involving decreased Eph receptor cell surface localization seems unlikely (Yin et al. 2004; Carvalho et al. 2006), the association with coexpressed ephrins might in- duce Eph receptor translocation to an environment rich in phosphotyrosine phosphatases or sterically inhibit Eph receptor clustering, which is necessary for activation. Through cis attenuation of Eph receptor forward signaling, coexpressed ephrins can fine-tune the responsiveness of cells to ephrins in trans beyond what is achieved by mere regulation of Eph receptor levels.

\section{Ephrin-Independent Activities of Eph Receptors}

In addition to their ephrin-dependent activities, the Eph receptors can signal independently of ephrin ligands, for example through cross talk with other receptor systems and cytoplasmic signaling molecules. Ephrin-independent signaling can have opposite effects compared to ephrin-dependent signaling, as exemplified by EphA2. This receptor is widely up-regulated in many cancers, which often correlates with low ephrin-A expression or failure of coexpressed ephrin-As to activate forward signaling (Zelinski et al. 2001; Macrae et al. 2005; Wykosky et al. 2005; Pasquale 2010; Tandon et al. 2011). This is consistent with the ability of EphA2 forward signaling to inhibit the Ras-Erk, Akt-mTORC1 and other oncogenic pathways. However, EphA2 overexpression can induce oncogenic transformation, suggesting that this receptor also has tumor-promoting activities that may not depend on ephrin binding (Zelinski et al. 2001; Tandon et al. 2011; Udayakumar et al. 2011). Recent studies have begun to unravel the mechanism of tumor promotion by EphA2. In cancer cells where Akt is highly activated by oncogenic mutations or growth factor stimulation, EphA2 is phosphorylated at S897 by Akt, which leads to an increase in cell migration/invasion that is independent of both ephrin binding and EphA2 kinase activity (Fig. 4C) (Miao et al. 2009). Other stimuli increasing Akt activation also cause S897 phosphorylation. For example, binding of extracellular Hsp90 to the LRP1 receptor induces Akt-dependent EphA2 S897 phosphorylation and association of EphA2 with LRP1, leading to glioblastoma cell invasiveness (Gopal et al. 2011). Moreover, ephrin-B3 expression in 
Eph Receptor Signaling and Ephrins

lung cancer cells can enhance the levels of EphA2 in its $\mathrm{S} 897$ phosphorylated form, concomitant with increasing resistance to $\gamma$-radiation (Stahl et al. 2011). Because ephrin-B3 has poor affinity for the ephrin-binding pocket of EphA2 (Gale et al. 1996), it will be interesting to investigate the connection between ephrin-B3 and EphA2 phosphorylation.

Remarkably, EphA2 seems to be at least in part responsible for the proliferative, migratory and tumorigenic activities of the EGF RTK family, as shown in several cultured cancer cell lines and in a mouse ErbB2 mammary tumor model (Larsen et al. 2007; Brantley-Sieders et al. 2008; Hiramoto-Yamaki et al. 2010; Argenzio et al. 2011). EGF stimulation can promote the association of EphA2 with the Rho-GEF Ephexin4, and it will be interesting to investigate the involvement of S897 phosphorylation in this ephrin-independent association (HiramotoYamaki et al. 2010). The EphA2-Ephexin4 interaction promotes RhoG activation and recruitment of the RhoG-GTP-binding protein ELMO2 and the Rac-GEF DOCK4 to EphA2, leading to Racl activation and cancer cell invasiveness (Fig. 4C). The EphA2-Ephexin4-RhoG pathway also suppresses cell death due to detachment from the extracellular matrix (anoikis) in epithelial and cancer cells (Harada et al. 2011). This involves activation of PI3 kinase and Akt, which might also create a positive feedback loop further enhancing EphA2 S897 phosphorylation. Overexpression of EphB3 was also recently shown to promote lung cancer cell tumorigenicity through a kinase-independent mechanism (Ji et al. 2011). It will be important to investigate the full extent of ephrin- and kinase-independent activities of Eph receptors and how they differ from forward signaling.

\section{Dephosphorylation}

Phosphotyrosine phosphatases can modulate the Eph receptor/ephrin system by terminating forward signaling and favoring tyrosine phosphorylation-independent activities. For instance, the cytoplasmic phosphotyrosine phosphatase LMW-PTP can dephosphorylate EphA2, thus counteracting the tumor suppressive effects of
EphA2 forward signaling and promoting cell transformation (Kikawa et al. 2002; Chiarugi et al. 2004; Parri et al. 2005). Similarly, the cytoplasmic phosphotyrosine phosphatase PTP1B can attenuate ephrin-induced EphA3 phosphorylation, endocytosis, and repulsive effects (Nievergall et al. 2010), while elevated endogenous phosphatase activity in pre-B leukemia cells can switch the EphA3-mediated response to ephrins from repulsion to adhesion (Wimmer-Kleikamp et al. 2008). In addition, PTP1B anchored to the endoplasmic reticulum has been reported to dephosphorylate EphA2 at sites of cell-cell contact where the endoplasmic reticulum comes in close proximity to the plasma membrane (Haj et al. 2012). Phosphatase activity induced by glucose in pancreatic $\beta$ cells attenuates EphA phosphorylation and forward signaling, which are inhibitory for insulin secretion (Konstantinova et al. 2007). The protein tyrosine phosphatase receptor type $\mathrm{O}$ can dephosphorylate both EphA and EphB receptors, and it targets in particular the second of the two conserved phosphotyrosine residues in the juxtamembrane domain, which is the most critical for activation (Shintani et al. 2006). The LAR protein tyrosine phosphatase receptor can dephosphorylate EphB2, and LAR down-regulation by the FGF RTK results in increased ephrin-independent EphB2 tyrosine phosphorylation (Poliakov et al. 2008). LMW-PTP is also involved in EphB receptor signaling, being recruited to EphB clusters to promote cell attachment (Stein et al. 1998). However, it is not known whether this involves EphB receptor dephosphorylation by the phosphatase. Furthermore, the lipid phosphatase Ship2 can interact with EphA2 and decrease its ephrin-dependent tyrosine phosphorylation, internalization, and degradation through a mechanism likely not involving direct receptor dephosphorylation (Zhuang et al. 2007; Lee et al. 2012). Other phosphotyrosine phosphatases, such as the PDZ domain-containing PTP-BL, dephosphorylate ephrin-Bs to terminate reverse signaling (Palmer et al. 2002). Future studies will likely implicate additional phosphatases, including serine/threonine phosphatases (Yang et al. 2011), in the regulation of Eph receptor/ephrin signaling. 
E.M. Lisabeth et al.

\section{GENE MUTATIONS}

Given the importance of the Eph receptor/ephrin system in developmental processes and adult tissue homeostasis, it is not surprising that its aberrant functioning has been implicated in a variety of diseases (Pasquale 2008, 2010). In particular, somatic and germline mutations in Eph receptors and ephrin genes are beginning to be linked to cancer and other pathologies. Largescale sequencing of tumor specimens identified somatic mutations in all the Eph receptors, with frequencies of up to $2 \%-6 \%$ for some Eph receptors in lung cancer and melanoma (Ding et al. 2008; Prickett et al. 2009; Peifer et al. 2012) (www.sanger.ac.uk/genetics/CGP/cosmic). The mutations are scattered throughout the Eph receptor domains (Fig. 5), and their functional consequences are mostly unknown. However, many of the nearly 40 missense mutations identified in EphA3 (Fig. 5), the receptor found to be the most highly mutated in cancer, have been recently shown to cause various degrees of loss-of-function through multiple mechanisms

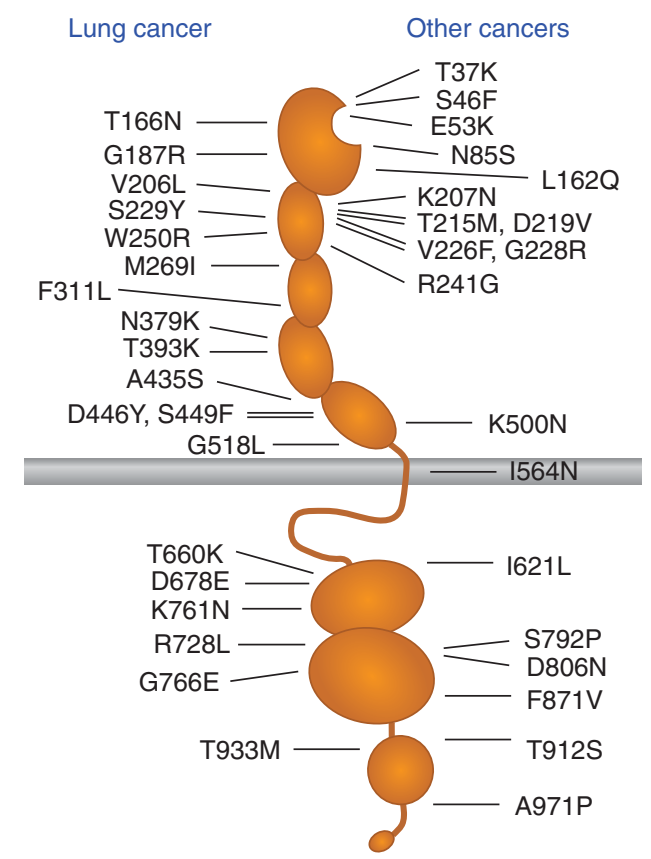

Figure 5. EphA3 receptor somatic mutations in cancer.
(Lisabeth et al. 2012; Zhuang et al. 2012). Most mutations in the ephrin-binding domain and the neighboring sushi domain impair ephrin binding either by directly affecting the high affinity ephrin-binding pocket or by causing overall conformational alterations. Mutations in the EphA3 kinase domain inhibit receptor tyrosine phosphorylation and kinase activity. A further consequence of many EphA3 mutations is a reduction in cell surface localization, which suggests that the mutations cause misfolding and/ or alter receptor trafficking.

These findings suggest that the mutations disrupt a tumor suppressive function of EphA3 that depends on ephrin binding and kinase activity and, thus, forward signaling. The EphA3 cancer mutations indeed have different characteristics compared to mutations in other RTK families, which are typically clustered in "hot spots" and promote constitutive activation and tumorigenesis (Lee et al. 2006; Sharma et al. 2007; Greulich and Pollock 2011). Furthermore, wild-type EphA3, but not several mutants identified in tumor specimens, can suppress lung cancer cell growth in mouse xenograft models of lung cancer (Zhuang et al. 2012). Two mutations in EphA6 and EphA7 correspond to inactivating mutations in EphA3, suggesting that these Eph receptors may also suppress tumorigenesis (Lisabeth et al. 2012). EphB2 inactivating mutations identified in prostate cancer also suggested a tumor suppressor role for this receptor, consistent with the growth inhibition induced by EphB2 overexpressed in DU145 prostate cancer cells (Huusko et al. 2004). However, other Eph receptors like EphA2 or EphA4 do not seem to be frequently mutated in cancer, perhaps suggesting differences in the oncogenic activities of these receptors. A mutation in the first FNIII domain of EphA2 identified in lung cancer has indeed been proposed to promote invasiveness and survival (Faoro et al. 2010).

Although classical tumor suppressors are typically inactivated by homozygous mutations, most of the EphA3 inactivating mutations are heterozygous (Lisabeth et al. 2012). Hence, the EphA3 mutants may act as dominant negatives, disrupting the function of the wild-type receptor (Zhuang et al. 2012) and possibly other Eph 
Eph Receptor Signaling and Ephrins

receptors that may be part of the same signaling clusters. Furthermore, concurrent mutations in multiple Eph receptors have been found in a relatively high proportion of tumor samples, suggesting that they may be advantageous for tumor cells by more severely disrupting signaling in Eph receptor clusters than a single mutation (Lisabeth et al. 2012).

Germline mutations in Eph receptors and ephrins also play a role in human disease. For instance, EphA2 mutations enhancing basal receptor activation or possibly increasing EphA2 association with the LMW-PTP phosphatase have been associated with cataract development (Shiels et al. 2008; Jun et al. 2009; Zhang et al. $2009 \mathrm{~b})$. Inactivating mutations in the X-linked ephrin-B1 gene cause craniofrontonasal syndrome as a result of inhibition of gap junctional communication and improper tissue boundary formation in the developing skull (Bush and Soriano 2010; Makarov et al. 2010; Zafeiriou et al. 2011). On the other hand, loss-of-function EphA4 mutations in amyotrophic lateral sclerosis patients are associated with long survival (Van Hoecke et al. 2012) and single nucleotide polymorphisms in various Eph receptors and ephrins have been implicated as modifiers in the pathogenesis of amyotrophic lateral sclerosis as well as Parkinson's disease (Lesnick et al. 2008). Furthermore, a common EphA1 polymorphism was recently associated with lateonset Alzheimer's disease (Naj et al. 2011) and an EphA6 polymorphism with responsiveness to an antischizophrenic drug (Ikeda et al. 2010). Studies on the functional effects of Eph receptor and ephrin mutations and polymorphisms will undoubtedly provide a wealth of new information on the physiological and pathological roles of this intriguingly complex signaling system.

\section{CONCLUDING REMARKS}

Understanding signaling by the Eph RTK family has been challenging because of the many idiosyncrasies that distinguish it from the other RTK families. The peculiar characteristics of the Eph RTKs include the membrane-bound nature of the ephrins, the bidirectional mode of Eph re- ceptor-ephrin signaling, the ability of the ephrins to stimulate but also attenuate Eph receptor signaling, and the ability of the Eph receptors to signal without ephrin involvement and even independently of kinase activity. Given the emerging view that different coexpressed Eph receptors signal cooperatively (Janes et al. 2011), to correctly interpret the results of signaling studies it will be important to profile the entire repertoire of Eph receptors present in a biological system (Noberini et al. 2012b) as well as survey their posttranslational modifications, including tyrosine and serine/threonine phosphorylation and ubiquitination. Systems biology approaches are also essential for a comprehensive understanding of the complexities of Eph receptor signaling networks and feedback loops, and the ability of these receptors to produce widely different biological outcomes (Jorgensen et al. 2009; Bush and Soriano 2012). In vivo analysis of Eph receptor/ephrin signaling as well as perturbations by designed or naturally occurring mutations and gene deletions will be critical to elucidate Eph receptor/ephrin physiological functions in the complex in vivo environment. Many fascinating activities of the Eph/ephrin system are only beginning to be appreciated, including key roles in stem cell biology (Genander and Frisen 2010) and in diseases such as Alzheimer's (Cisse et al. 2011; Hollingworth et al. 2011), or their emerging ability to regulate microRNAs (Arvanitis et al. 2010; Bhushan and Kandpal 2011; Khodayari et al. 2011) and gene transcription (Lai et al. 2004; Bong et al. 2007; Bush and Soriano 2010, 2012; Parrinello et al. 2010). Resolution of the paradoxes that plague our understanding of Eph receptor/ephrin function will enable effective exploitation of the many therapeutic opportunities that the Eph/ephrin system offers (Pasquale 2010; Noberini et al. 2012a).

\section{ACKNOWLEDGMENTS}

The authors thank R. Noberini, Y. Wallez, and A. Barquilla for helpful comments on the manuscript. Work in the authors' laboratory is supported by grants from the National Institutes of Health and the Tobacco-Related Disease Re- 
E.M. Lisabeth et al.

search Grants Program Office of the University of California.

\section{REFERENCES}

${ }^{*}$ Reference is also in this collection.

Afshari FT, Kwok JC, Fawcett JW. 2010. Astrocyte-produced ephrins inhibit Schwann cell migration via VAV2 signaling. J Neurosci 30: 4246-4255.

Antion MD, Christie LA, Bond AM, Dalva MB, Contractor A. 2010. Ephrin-B3 regulates glutamate receptor signaling at hippocampal synapses. Mol Cell Neurosci 45: $378-$ 388.

Argenzio E, Bange T, Oldrini B, Bianchi F, Peesari R, Mari S, Di Fiore PP, Mann M, Polo S. 2011. Proteomic snapshot of the EGF-induced ubiquitin network. Mol Syst Biol 7: 462.

Arvanitis D, Davy A. 2008. Eph/ephrin signaling: Networks. Genes Dev 22: 416-429.

Arvanitis DN, Jungas T, Behar A, Davy A. 2010. Ephrin-B1 reverse signaling controls a posttranscriptional feedback mechanism via miR-124. Mol Cell Biol 30: 25082517.

Astin JW, Batson J, Kadir S, Charlet J, Persad RA, Gillatt D, Oxley JD, Nobes CD. 2010. Competition amongst Eph receptors regulates contact inhibition of locomotion and invasiveness in prostate cancer cells. Nat Cell Biol 12: 1194-1204.

Attwood BK, Bourgognon JM, Patel S, Mucha M, Schiavon E, Skrzypiec AE, Young KW, Shiosaka S, Korostynski M, Piechota M, et al. 2011. Neuropsin cleaves EphB2 in the amygdala to control anxiety. Nature 473: 372-375.

Baba A, Akagi K, Takayanagi M, Flanagan JG, Kobayashi T, Hattori M. 2009. Fyn tyrosine kinase regulates the surface expression of glycosylphosphatidylinositol-linked ephrin via the modulation of sphingomyelin metabolism. J Biol Chem 284: 9206-9214.

Bartley TD, Hunt RW, Welcher AA, Boyle WJ, Parker VP, Lindberg RA, Lu HS, Colombero AM, Elliott RL, Guthrie BA. 1994. B61 is a ligand for the ECK receptor proteintyrosine kinase. Nature 368: 558-560.

* Barton WA, Dalton AC, Seegar TCM, Himanen JP, Nikolov DB. 2013. Tie2 and Eph receptor tyrosine kinase activation and signaling. Cold Spring Harb Perspect Biol doi: 10.1101/cshperspect.a009142.

Beg AA, Sommer JE, Martin JH, Scheiffele P. 2007. $\alpha 2$-Chimaerin is an essential EphA4 effector in the assembly of neuronal locomotor circuits. Neuron 55: 768-778.

Bhushan L, Kandpal RP. 2011. EphB6 receptor modulates micro RNA profile of breast carcinoma cells. PLoS ONE 6 e22484.

Binns KL, Taylor PP, Sicheri F, Pawson T, Holland SJ. 2000. Phosphorylation of tyrosine residues in the kinase domain and juxtamembrane region regulates the biological and catalytic activities of Eph receptors. Mol Cell Biol 20: 4791-4805.

Bohme B, VandenBos T, Cerretti DP, Park LS, Holtrich U, Rubsamen-Waigmann H, Strebhardt K. 1996. Cell-cell adhesion mediated by binding of membrane-anchored ligand LERK-2 to the EPH-related receptor human em- bryonal kinase 2 promotes tyrosine kinase activity. J Biol Chem 271: 24747-24752.

Bonanomi D, Chivatakarn O, Bai G, Abdesselem H, Lettieri K, Marquardt T, Pierchala BA, Pfaff SL. 2012. Ret is a multifunctional coreceptor that integrates diffusibleand contact-axon guidance signals. Cell 148: 568-582.

Bong YS, Lee HS, Carim-Todd L, Mood K, Nishanian TG, Tessarollo L, Daar IO. 2007. ephrin-B1 signals from the cell surface to the nucleus by recruitment of STAT3. Proc Natl Acad Sci 104: 17305-17310.

Bouzioukh F, Wilkinson GA, Adelmann G, Frotscher M, Stein V, Klein R. 2007. Tyrosine phosphorylation sites in ephrin-B2 are required for hippocampal long-term potentiation but not long-term depression. J Neurosci 27: 11279-11288.

Brantley-Sieders DM, Zhuang G, Hicks D, Fang WB, Hwang Y, Cates JM, Coffman K, Jackson D, Bruckheimer E, Muraoka-Cook RS, et al. 2008. The receptor tyrosine kinase EphA2 promotes mammary adenocarcinoma tumorigenesis and metastatic progression in mice by amplifying ErbB2 signaling. J Clin Invest 118: 64-78.

Bush JO, Soriano P. 2009. Ephrin-B1 regulates axon guidance by reverse signaling through a PDZ-dependent mechanism. Genes Dev 23: 1586-1599.

Bush JO, Soriano P. 2010. Ephrin-B1 forward signaling regulates craniofacial morphogenesis by controlling cell proliferation across Eph-ephrin boundaries. Genes Dev 24: 2068-2080.

Bush JO, Soriano P. 2012. Eph/ephrin signaling: Genetic, phosphoproteomic, and transcriptomic approaches. Semin Cell Dev Biol 23: 26-34.

Campbell TN, Attwell S, Arcellana-Panlilio M, Robbins SM. 2006. Ephrin-A5 expression promotes invasion and transformation of murine fibroblasts. Biochem Biophys Res Commun 350: 623-628.

Carmona MA, Murai KK, Wang L, Roberts AJ, Pasquale EB. 2009. Glial ephrin-A3 regulates hippocampal dendritic spine morphology and glutamate transport. Proc Natl Acad Sci 106: $12524-12529$.

Carvalho RF, Beutler M, Marler KJ, Knoll B, Becker-Barroso E, Heintzmann R, Ng T, Drescher U. 2006. Silencing of EphA3 through a cis interaction with ephrin-A5. Nat Neurosci 9: 322-330.

Chandarlapaty S, Sawai A, Scaltriti M, Rodrik-Outmezguine V, Grbovic-Huezo O, Serra V, Majumder PK, Baselga J, Rosen N. 2011. AKT inhibition relieves feedback suppression of receptor tyrosine kinase expression and activity. Cancer Cell 19: 58-71.

Chang Q, Jorgensen C, Pawson T, Hedley DW. 2008. Effects of dasatinib on EphA2 receptor tyrosine kinase activity and downstream signalling in pancreatic cancer. $\mathrm{Br} J$ Cancer 99: 1074-1082.

Chiarugi P, Taddei ML, Schiavone N, Papucci L, Giannoni E, Fiaschi T, Capaccioli S, Raugei G, Ramponi G. 2004 LMW-PTP is a positive regulator of tumor onset and growth. Oncogene 23: 3905-3914.

Cisse M, Halabisky B, Harris J, Devidze N, Dubal DB, Sun B, Orr A, Lotz G, Kim DH, Hamto P, et al. 2011. Reversing EphB2 depletion rescues cognitive functions in Alzheimer model. Nature 469: 47-52. 
Cowan CA, Henkemeyer M. 2001. The SH2/SH3 adaptor Grb4 transduces B-ephrin reverse signals. Nature 413: $174-179$.

Cowan CW, Shao YR, Sahin M, Shamah SM, Lin MZ, Greer PL, Gao S, Griffith EC, Brugge JS, Greenberg ME. 2005. Vav family GEFs link activated Ephs to endocytosis and axon guidance. Neuron 46: 205-217.

Dail M, Richter M, Godement P, Pasquale EB. 2006. Eph receptors inactivate R-Ras through different mechanisms to achieve cell repulsion. J Cell Sci 119: 1244-1254.

Davy A, Gale NW, Murray EW, Klinghoffer RA, Soriano P, Feuerstein C, Robbins SM. 1999. Compartmentalized signaling by GPI-anchored ephrin-A5 requires the Fyn tyrosine kinase to regulate cellular adhesion. Genes Dev 13: 3125-3135.

Davy A, Feuerstein C, Robbins SM. 2000. Signaling within a caveolae-like membrane microdomain in human neuroblastoma cells in response to fibroblast growth factor. J Neurochem 74: 676-683.

Davy A, Bush JO, Soriano P. 2006. Inhibition of gap junction communication at ectopic Eph/ephrin boundaries underlies craniofrontonasal syndrome. PLoS Biol 4: e315.

Ding L, Getz G, Wheeler DA, Mardis ER, McLellan MD, Cibulskis K, Sougnez C, Greulich H, Muzny DM, Morgan MB, et al. 2008. Somatic mutations affect key pathways in lung adenocarcinoma. Nature 455: 1069-1075.

Du J, Fu C, Sretavan DW. 2007. Eph/ephrin signaling as a potential therapeutic target after central nervous system injury. Curr Pharm Des 13: 2507-2518.

Elowe S, Holland SJ, Kulkarni S, Pawson T. 2001. Downregulation of the Ras-mitogen-activated protein kinase pathway by the EphB2 receptor tyrosine kinase is required for ephrin-induced neurite retraction. Mol Cell Biol 21: 7429-7441.

Essmann CL, Martinez E, Geiger JC, Zimmer M, Traut MH, Stein V, Klein R, Acker-Palmer A. 2008. Serine phosphorylation of ephrin-B2 regulates trafficking of synaptic AMPA receptors. Nat Neurosci 11: 1035-1043.

Faoro L, Singleton PA, Cervantes GM, Lennon FE, Choong NW, Kanteti R, Ferguson BD, Husain AN, Tretiakova MS, Ramnath N, et al. 2010. EphA2 mutation in lung squamous cell carcinoma promotes increased cell survival, cell invasion, focal adhesions, and mammalian target of rapamycin activation. J Biol Chem 285: 18575-18585.

Fasen K, Cerretti DP, Huynh-Do U. 2008. Ligand binding induces Cbl-dependent EphB1 receptor degradation through the lysosomal pathway. Traffic 9: 251-266.

Filosa A, Paixao S, Honsek SD, Carmona MA, Becker L, Feddersen B, Gaitanos L, Rudhard Y, Schoepfer R, Klopstock T, et al. 2009. Neuron-glia communication via EphA4/ephrin-A3 modulates LTP through glial glutamate transport. Nat Neurosci 12: 1285-1292.

Fu WY, Chen Y, Sahin M, Zhao XS, Shi L, Bikoff JB, Lai KO, Yung WH, Fu AK, Greenberg ME, et al. 2007. Cdk5 regulates EphA4-mediated dendritic spine retraction through an ephexin1-dependent mechanism. Nat Neurosci 10: 67-76.

Gale NW, Flenniken A, Compton DC, Jenkins N, Copeland NG, Gilbert DJ, Davis S, Wilkinson DG, Yancopoulos GD. 1996. Elk-L3, a novel transmembrane ligand for the Eph family of receptor tyrosine kinases, expressed in embryonic floor plate, roof plate and hindbrain segments. Oncogene 13: 1343-1352.

Genander M, Frisen J. 2010. Ephrins and Eph receptors in stem cells and cancer. Curr Opin Cell Biol 22: 611-616.

Georgakopoulos A, Litterst C, Ghersi E, Baki L, Xu C, Serban G, Robakis NK. 2006. Metalloproteinase/Presenilin1 processing of ephrin-B regulates EphB-induced Src phosphorylation and signaling. EMBO J 25: 1242-1252.

Georgakopoulos A, Xu J, Xu C, Mauger G, Barthet G, Robakis NK. 2011. Presenilin $1 / \gamma$-secretase promotes the EphB2-induced phosphorylation of ephrin-B2 by regulating phosphoprotein associated with glycosphingolipid-enriched microdomains/Csk binding protein. FASEB J 25: 3594-3604.

* Goh LK, Sorkin A. 2013. Endocytosis of receptor tyrosine kinases. Cold Spring Harb Perspect Biol doi: 10.1101/ cshperspect.a017459.

Gopal U, Bohonowych JE, Lema-Tome C, Liu A, GarrettMayer E, Wang B, Isaacs JS. 2011. A novel extracellular Hsp90 mediated co-receptor function for LRP1 regulates EphA2-dependent glioblastoma cell invasion. PLoS ONE 6: e17649.

Greulich H, Pollock PM. 2011. Targeting mutant fibroblast growth factor receptors in cancer. Trends $\mathrm{Mol} \mathrm{Med} \mathrm{17:}$ 283-292.

Haj FG, Sabet O, Kinkhabwala A, Wimmer-Kleikamp S, Roukos V, Han HM, Grabenbauer M, Bierbaum M, Antony C, Neel BG, et al. 2012. Regulation of signaling at regions of cell-cell contact by endoplasmic reticulumbound protein-tyrosine phosphatase 1B. PLOS ONE 7: e36633.

Harada K, Hiramoto-Yamaki N, Negishi M, Katoh H. 2011. Ephexin4 and EphA2 mediate resistance to anoikis through RhoG and phosphatidylinositol 3-kinase. Exp Cell Res 317: 1701-1713.

Hattori M, Osterfield M, Flanagan JG. 2000. Regulated cleavage of a contact-mediated axon repellent. Science 289: $1360-1365$.

Heasman SJ, Ridley AJ. 2008. Mammalian Rho GTPases: New insights into their functions from in vivo studies. Nat Rev Mol Cell Biol 9: 690-701.

Himanen JP, Yermekbayeva L, Janes PW, Walker JR, Xu K, Atapattu L, Rajashankar KR, Mensinga A, Lackmann M, Nikolov DB, et al. 2010. Architecture of Eph receptor clusters. Proc Natl Acad Sci 107: 10860-10865.

Hiramoto-Yamaki N, Takeuchi S, Ueda S, Harada K, Fujimoto S, Negishi M, Katoh H. 2010. Ephexin4 and EphA2 mediate cell migration through a RhoG-dependent mechanism. J Cell Biol 190: 461-477.

Holen HL, Shadidi M, Narvhus K, Kjosnes O, Tierens A, Aasheim HC. 2008. Signaling through ephrin-A ligand leads to activation of Src-family kinases, Akt phosphorylation, and inhibition of antigen receptor-induced apoptosis. J Leukoc Biol 84: 1183-1191.

Holen HL, Zernichow L, Fjelland KE, Evenroed IM, Prydz K, Tveit H, Aasheim HC. 2011. Ephrin-B3 binds to a sulfated cell-surface receptor. Biochem J 433: 215-223.

Hollingworth P, Harold D, Sims R, Gerrish A, Lambert JC Carrasquillo MM, Abraham R, Hamshere ML, Pahwa JS, Moskvina V, et al. 2011. Common variants at ABCA7, 
E.M. Lisabeth et al.

MS4A6A/MS4A4E, EPHA1, CD33 and CD2AP are associated with Alzheimer's disease. Nat Genet 43: 429-435.

Holmberg J, Clarke DL, Frisen J. 2000. Regulation of repulsion versus adhesion by different splice forms of an Eph receptor. Nature 408: 203-206.

Holmberg J, Armulik A, Senti KA, Edoff K, Spalding K, Momma S, Cassidy R, Flanagan JG, Frisen J. 2005. Ephrin-A2 reverse signaling negatively regulates neural progenitor proliferation and neurogenesis. Genes Dev 19: 462-471.

Hornberger MR, Dutting D, Ciossek T, Yamada T, Handwerker C, Lang S, Weth F, Huf J, Wessel R, Logan C, et al. 1999. Modulation of EphA receptor function by coexpressed ephrin-A ligands on retinal ganglion cell axons. Neuron 22: 731-742.

Huang X, Wu D, Jin H, Stupack D, Wang JY. 2008. Induction of cell retraction by the combined actions of Abl-CrkI and Rho-ROCK1 signaling. J Cell Biol 183: 711-723.

Hunter SG, Zhuang G, Brantley-Sieders D, Swat W, Cowan CW, Chen J. 2006. Essential role of vav family guanine nucleotide exchange factors in epha receptor-mediated angiogenesis. Mol Cell Biol 26: 4830-4842.

Huusko P, Ponciano-Jackson D, Wolf M, Kiefer JA, Azorsa DO, Tuzmen S, Weaver D, Robbins C, Moses T, Allinen $\mathrm{M}$, et al. 2004. Nonsense-mediated decay microarray analysis identifies mutations of EPHB2 in human prostate cancer. Nat Genet 36: 979-983.

Ikeda M, Tomita Y, Mouri A, Koga M, Okochi T, Yoshimura R, Yamanouchi Y, Kinoshita Y, Hashimoto R, Williams $\mathrm{HJ}$, et al. 2010. Identification of novel candidate genes for treatment response to risperidone and susceptibility for schizophrenia: Integrated analysis among pharmacogenomics, mouse expression, and genetic case-control association approaches. Biol Psychiatry 67: 263-269.

Inoue E, Deguchi-Tawarada M, Togawa A, Matsui C, Arita K, Katahira-Tayama S, Sato T, Yamauchi E, Oda Y, Takai Y 2009. Synaptic activity prompts $\gamma$-secretase-mediated cleavage of EphA4 and dendritic spine formation. J Cell Biol 185: 551-564.

Irie F, Yamaguchi Y. 2002. EphB receptors regulate dendritic spine development via intersectin, Cdc42 and N-WASP. Nat Neurosci 5: 1117-1118.

Irie F, Okuno M, Matsumoto K, Pasquale EB, Yamaguchi Y. 2008. Heparan sulfate regulates ephrin-A3/EphA receptor signaling. Proc Natl Acad Sci 105: 12307-12312.

Iwasato $\mathrm{T}$, Katoh $\mathrm{H}$, Nishimaru $\mathrm{H}$, Ishikawa $\mathrm{Y}$, Inoue $\mathrm{H}$, Saito YM, Ando R, Iwama M, Takahashi R, Negishi M, et al. 2007. Rac-GAP $\alpha$-chimerin regulates motor-circuit formation as a key mediator of ephrin-B3/EphA4 forward signaling. Cell 130: 742-753.

Janes PW, Saha N, Barton WA, Kolev MV, Wimmer-Kleikamp SH, Nievergall E, Blobel CP, Himanen JP, Lackmann M, Nikolov DB. 2005. Adam meets Eph: An ADAM substrate recognition module acts as a molecular switch for ephrin cleavage in trans. Cell 123: 291-304.

Janes PW, Wimmer-Kleikamp SH, Frangakis AS, Treble K, Griesshaber B, Sabet O, Grabenbauer M, Ting AY, Saftig P, Bastiaens PI, et al. 2009. Cytoplasmic relaxation of active Eph controls ephrin shedding by ADAM10. PLoS Biol 7: e1000215.

Janes PW, Griesshaber B, Atapattu L, Nievergall E, Hii LL, Mensinga A, Chheang C, Day BW, Boyd AW, Bastiaens PI, et al. 2011. Eph receptor function is modulated by heterooligomerization of A and B type Eph receptors. J Cell Biol 195: 1033-1045.

Ji XD, Li G, Feng YX, Zhao JS, Li JJ, Sun ZJ, Shi S, Deng YZ, $\mathrm{Xu}$ JF, Zhu YQ, et al. 2011. EphB3 is overexpressed in nonsmall-cell lung cancer and promotes tumor metastasis by enhancing cell survival and migration. Cancer Res 71: 1156-1166.

Jorgensen C, Sherman A, Chen GI, Pasculescu A, Poliakov A, Hsiung M, Larsen B, Wilkinson DG, Linding R, Pawson T. 2009. Cell-specific information processing in segregating populations of Eph receptor ephrin-expressing cells. Science 326: 1502-1509.

Jun G, Guo H, Klein BE, Klein R, Wang JJ, Mitchell P, Miao H, Lee KE, Joshi T, Buck M, et al. 2009. EPHA2 is associated with age-related cortical cataract in mice and humans. PLoS Genet 5: e1000584.

Kao TJ, Kania A. 2011. Ephrin-mediated cis-attenuation of Eph receptor signaling is essential for spinal motor axon guidance. Neuron 71: 76-91.

Khodayari N, Mohammed KA, Goldberg EP, Nasreen N. 2011. Ephrin-A1 inhibits malignant mesothelioma tumor growth via let-7 microRNA-mediated repression of the RAS oncogene. Cancer Gene Ther 18: 806-816.

Kikawa KD, Vidale DR, Van Etten RL, Kinch MS. 2002. Regulation of the EphA2 kinase by the low molecular weight tyrosine phosphatase induces transformation. $J$ Biol Chem 277: 39274-39279.

Klein R. 2009. Bidirectional modulation of synaptic functions by Eph/ephrin signaling. Nat Neurosci 12: 15-20.

Konstantinova I, Nikolova G, Ohara-Imaizumi M, Meda P, Kucera T, Zarbalis K, Wurst W, Nagamatsu S, Lammert E. 2007. EphA-Ephrin-A-mediated $\beta$ cell communication regulates insulin secretion from pancreatic islets. Cell 129: $359-370$.

Lackmann M, Boyd AW. 2008. Eph, a protein family coming of age: More confusion, insight, or complexity? Sci Signal 1: re2.

Lai KO, Chen Y, Po HM, Lok KC, Gong K, Ip NY. 2004. Identification of the Jak/Stat proteins as novel downstream targets of EphA4 signaling in muscle: Implications in the regulation of acetylcholinesterase expression. J Biol Chem 279: 13383-13392.

Larsen AB, Pedersen MW, Stockhausen MT, Grandal MV, van Deurs B, Poulsen HS. 2007. Activation of the EGFR gene target EphA2 inhibits epidermal growth factor-induced cancer cell motility. Mol Cancer Res 5: 283-293.

Lee JC, Vivanco I, Beroukhim R, Huang JH, Feng WL, DeBiasi RM, Yoshimoto K, King JC, Nghiemphu P, Yuza Y, et al. 2006. Epidermal growth factor receptor activation in glioblastoma through novel missense mutations in the extracellular domain. PLoS Med 3: e485.

Lee HS, Nishanian TG, Mood K, Bong YS, Daar IO. 2008. Ephrin-B1 controls cell-cell junctions through the Par polarity complex. Nat Cell Biol 10: 979-986.

Lee HJ, Hota PK, Chugha P, Guo H, Miao H, Zhang L, Kim SJ, Stetzik L, Wang BC, Buck M. 2012. NMR Structure of a heterodimeric SAM:SAM complex: Characterization and manipulation of epha2 binding reveal new cellular functions of SHIP2. Structure 20: 41-55. 
Eph Receptor Signaling and Ephrins

Lesnick TG, Sorenson EJ, Ahlskog JE, Henley JR, Shehadeh L, Papapetropoulos S, Maraganore DM. 2008. Beyond Parkinson disease: Amyotrophic lateral sclerosis and the axon guidance pathway. PLoS ONE 3: e1449.

Li JJ, Liu DP, Liu GT, Xie D. 2009. Ephrin-A5 acts as a tumor suppressor in glioma by negative regulation of epidermal growth factor receptor. Oncogene 28: 1759-1768.

Li G, Ji XD, Gao H, Zhao JS, Xu JF, Sun ZJ, Deng YZ, Shi S, Feng YX, Zhu YQ, et al. 2012. EphB3 suppresses nonsmall-cell lung cancer metastasis via a PP2A/RACK1/ Akt signalling complex. Nat Commun 3: 667.

Lim YS, McLaughlin T, Sung TC, Santiago A, Lee KF, O'Leary DD. 2008. p75(NTR) mediates ephrin-A reverse signaling required for axon repulsion and mapping. $\mathrm{Neu}-$ ron 59: 746-758.

Lisabeth EM, Fernandez C, Pasquale EB. 2012. Cancer somatic mutations disrupt functions of the EphA3 receptor tyrosine kinase through multiple mechanisms. Biochemistry 51: 1464-1475.

Litterst C, Georgakopoulos A, Shioi J, Ghersi E, Wisniewski T, Wang R, Ludwig A, Robakis NK. 2007. Ligand binding and calcium influx induce distinct ectodomain $/ \gamma$-secretase-processing pathways of EphB2 receptor. J Biol Chem 282: $16155-16163$.

Lu Q, Sun EE, Klein RS, Flanagan JG. 2001. Ephrin-B reverse signaling is mediated by a novel PDZ-RGS protein and selectively inhibits $G$ protein-coupled chemoattraction. Cell 105: 69-79.

Macrae M, Neve RM, Rodriguez-Viciana P, Haqq C, Yeh J, Chen C, Gray JW, McCormick F. 2005. A conditional feedback loop regulates Ras activity through EphA2. Cancer Cell 8: 111-118.

Maddigan A, Truitt L, Arsenault R, Freywald T, Allonby O, Dean J, Narendran A, Xiang J, Weng A, Napper S, et al. 2011. EphB receptors trigger Akt activation and suppress Fas receptor-induced apoptosis in malignant $\mathrm{T}$ lymphocytes. J Immunol 187: 5983-5994.

Makarov R, Steiner B, Gucev Z, Tasic V, Wieacker P, Wieland I. 2010. The impact of CFNS-causing EFNB1 mutations on ephrin-B1 function. BMC Med Genet 11: 98.

Makinen T, Adams RH, Bailey J, Lu Q, Ziemiecki A, Alitalo K, Klein R, Wilkinson GA. 2005. PDZ interaction site in ephrin-B2 is required for the remodeling of lymphatic vasculature. Genes Dev 19: 397-410.

Manning BD, Cantley LC. 2007. AKT/PKB signaling: Navigating downstream. Cell 129: 1261-1274.

Margolis SS, Salogiannis J, Lipton DM, Mandel-Brehm C, Wills ZP, Mardinly AR, Hu L, Greer PL, Bikoff JB, Ho HY, et al. 2010. EphB-mediated degradation of the RhoA GEF Ephexin5 relieves a developmental brake on excitatory synapse formation. Cell 143: 442-455.

Marler KJ, Becker-Barroso E, Martinez A, Llovera M, Wentzel C, Poopalasundaram S, Hindges R, Soriano E, Comella J, Drescher U. 2008. A TrkB/Ephrin-A interaction controls retinal axon branching and synaptogenesis. $J$ Neurosci 28: 12700-12712.

Marler KJ, Poopalasundaram S, Broom ER, Wentzel C, Drescher U. 2010. Pro-neurotrophins secreted from retinal ganglion cell axons are necessary for ephrin-Ap75NTR-mediated axon guidance. Neural Dev 5: 30.
Marquardt T, Shirasaki R, Ghosh S, Andrews SE, Carter N, Hunter T, Pfaff SL. 2005. Coexpressed EphA receptors and ephrin-A ligands mediate opposing actions on growth cone navigation from distinct membrane domains. Cell 121: 127-139.

Marston DJ, Dickinson S, Nobes CD. 2003. Rac-dependent trans-endocytosis of ephrin-Bs regulates Eph-ephrin contact repulsion. Nat Cell Biol 5: 879-888.

McKay MM, Morrison DK. 2007. Integrating signals from RTKs to ERK/MAPK. Oncogene 26: 3113-3121.

Meier C, Anastasiadou S, Knoll B. 2011. Ephrin-A5 suppresses neurotrophin evoked neuronal motility, ERK activation and gene expression. PLoS ONE 6: e26089.

Mellitzer G, Xu QL, Wilkinson DG. 1999. Eph receptors and ephrins restrict cell intermingling and communication. Nature 400: 77-81.

Menges CW, McCance DJ. 2008. Constitutive activation of the Raf-MAPK pathway causes negative feedback inhibition of Ras-PI3K-AKT and cellular arrest through the EphA2 receptor. Oncogene 27: 2934-2940.

Miao H, Wei BR, Peehl DM, Li Q, Alexandrou T, Schelling JR, Rhim JS, Sedor JR, Burnett E, Wang BC. 2001. Activation of EphA receptor tyrosine kinase inhibits the Ras/ MAPK pathway. Nat Cell Biol 3: 527-530.

Miao H, Li DQ, Mukherjee A, Guo H, Petty A, Cutter J, Basilion JP, Sedor J, Wu J, Danielpour D, et al. 2009. EphA2 mediates ligand-dependent inhibition and ligand-independent promotion of cell migration and invasion via a reciprocal regulatory loop with Akt. Cancer Cell 16: 9-20.

Minami M, Koyama T, Wakayama Y, Fukuhara S, Mochizuki N. 2011. Ephrin-A/EphA signal facilitates insulinlike growth factor-I-induced myogenic differentiation through suppression of the Ras/extracellular signal-regulated kinase $1 / 2$ cascade in myoblast cell lines. Mol Biol Cell 22: $3508-3519$.

Moeller ML, Shi Y, Reichardt LF, Ethell IM. 2006. EphB receptors regulate dendritic spine morphogenesis through the recruitment/phosphorylation of focal adhesion kinase and RhoA activation. J Biol Chem 281: 15871598.

Murai KK, Nguyen LN, Irie F, Yamaguchi Y, Pasquale EB. 2003. Control of hippocampal dendritic spine morphology through ephrin-A3/EphA4 signaling. Nat Neurosci 6: $153-160$.

Naj AC, Jun G, Beecham GW, Wang LS, Vardarajan BN, Buros J, Gallins PJ, Buxbaum JD, Jarvik GP, Crane PK, et al. 2011. Common variants at MS4A4/MS4A6E, CD2AP, CD33 and EPHA1 are associated with late-onset Alzheimer's disease. Nat Genet 43: 436-441.

Nakada M, Drake KL, Nakada S, Niska JA, Berens ME. 2006. Ephrin-B3 ligand promotes glioma invasion through activation of Rac1. Cancer Res 66: 8492-8500.

Nie D, Di Nardo A, Han JM, Baharanyi H, Kramvis I, Huynh T, Dabora S, Codeluppi S, Pandolfi PP, Pasquale EB, et al. 2010. Tsc2-Rheb signaling regulates EphA-mediated axon guidance. Nat Neurosci 13: 163-172.

Nievergall E, Janes PW, Stegmayer C, Vail ME, Haj FG, Teng SW, Neel BG, Bastiaens PI, Lackmann M. 2010. PTP1B regulates Eph receptor function and trafficking. J Cell Biol 191: $1189-1203$. 
E.M. Lisabeth et al.

Noberini R, Lamberto I, Pasquale EB. 2012a. Targeting Eph receptors with peptides and small molecules: Progress and challenges. Semin Cell Dev Biol 23: 51-57.

Noberini R, Rubio de la Torre E, Pasquale EB. 2012b. Profiling Eph receptor expression in cells and tissues: A targeted mass spectrometry approach. Cell Adh Migr 6: $102-112$.

Oricchio E, Nanjangud G, Wolfe AL, Schatz JH, Mavrakis KJ, Jiang M, Liu X, Bruno J, Heguy A, Olshen AB, et al. 2011. The eph-receptor A7 is a soluble tumor suppressor for follicular lymphoma. Cell 147: 554-564.

Palmer A, Zimmer M, Erdmann KS, Eulenburg V, Porthin A, Heumann R, Deutsch U, Klein R. 2002. Ephrin-B phosphorylation and reverse signaling: Regulation by Src kinases and PTP-BL phosphatase. Mol Cell 9: 725-737.

Park EC, Cho GS, Kim GH, Choi SC, Han JK. 2011. The involvement of Eph-Ephrin signaling in tissue separation and convergence during Xenopus gastrulation movements. Dev Biol 350: 441-450.

Parri M, Buricchi F, Taddei ML, Giannoni E, Raugei G, Ramponi G, Chiarugi P. 2005. Ephrin-A1 repulsive response is regulated by an EphA2 tyrosine phosphatase. $J$ Biol Chem 280: 34008-34018.

Parrinello S, Napoli I, Ribeiro S, Digby PW, Fedorova M, Parkinson DB, Doddrell RD, Nakayama M, Adams RH, Lloyd AC. 2010. EphB signaling directs peripheral nerve regeneration through Sox2-dependent Schwann cell sorting. Cell 143: 145-155.

Pasquale EB. 2004. Eph-ephrin promiscuity is now crystal clear. Nat Neurosci 7: 417-418.

Pasquale EB. 2005. Eph receptor signalling casts a wide net on cell behaviour. Nat Rev Mol Cell Biol 6: 462-475.

Pasquale EB. 2008. Eph-ephrin bidirectional signaling in physiology and disease. Cell 133: 38-52.

Pasquale EB. 2010. Eph receptors and ephrins in cancer: Bidirectional signalling and beyond. Nat Rev Cancer 10: 165-180.

Peifer M, Fernandez-Cuesta L, Sos ML, George J, Seidel D, Kasper LH, Plenker D, Leenders F, Sun R, Zander T, et al. 2012. Integrative genome analyses identify key somatic driver mutations of small-cell lung cancer. Nat Genet 44: 1104-1110.

Penzes P, Beeser A, Chernoff J, Schiller MR, Eipper BA, Mains RE, Huganir RL. 2003. Rapid induction of dendritic spine morphogenesis by trans-synaptic Ephrin-BEphB receptor activation of the Rho-GEF Kalirin. Neuron 37: $263-274$.

Picco V, Hudson C, Yasuo H. 2007. Ephrin-Eph signalling drives the asymmetric division of notochord/neural precursors in Ciona embryos. Development 134: 1491-1497.

Pitulescu ME, Adams RH. 2010. Eph/ephrin molecules-A hub for signaling and endocytosis. Genes Dev 24: 2480 2492.

Poliakov A, Cotrina ML, Pasini A, Wilkinson DG. 2008. Regulation of EphB2 activation and cell repulsion by feedback control of the MAPK pathway. J Cell Biol 183: 933-947.

Prickett TD, Agrawal NS, Wei X, Yates KE, Lin JC, Wunderlich JR, Cronin JC, Cruz P, Rosenberg SA, Samuels Y 2009. Analysis of the tyrosine kinome in melanoma re- veals recurrent mutations in ERBB4. Nat Genet 41: 1127 1132.

Qiu R, Wang J, Tsark W, Lu Q. 2010. Essential role of PDZRGS3 in the maintenance of neural progenitor cells. Stem Cells 28: $1602-1610$

Richter M, Murai KK, Bourgin C, Pak D, Pasquale EB. 2007. The EphA4 receptor regulates neuronal morphology through SPAR-mediated inactivation of Rap GTPases. J Neurosci 27: 14205-14215.

Riedl JA, Brandt DT, Batlle E, Price LS, Clevers H, Bos JL. 2005. Down-regulation of Rap1 activity is involved in ephrin-B1-induced cell contraction. Biochem J 389: 465-469.

Rohani N, Canty L, Luu O, Fagotto F, Winklbauer R. 2011. Ephrin-B/EphB signaling controls embryonic germ layer separation by contact-induced cell detachment. PLoS Biol 9: $\mathrm{e} 1000597$.

Sahin M, Greer PL, Lin MZ, Poucher H, Eberhart J, Schmidt S, Wright TM, Shamah SM, O'Connell S, Cowan CW, et al. 2005. Eph-dependent tyrosine phosphorylation of ephexin1 modulates growth cone collapse. Neuron 46: 191-204.

Salaita K, Groves JT. 2010. Roles of the cytoskeleton in regulating EphA2 signals. Commun Integr Biol 3: 454-457.

Sawamiphak S, Seidel S, Essmann CL, Wilkinson GA, Pitulescu ME, Acker T, Acker-Palmer A. 2010. Ephrin-B2 regulates VEGFR2 function in developmental and tumour angiogenesis. Nature 465: 487-491.

* Schlessinger J. 2013. Receptor tyrosine kinases: Legacy of the first two decades. Cold Spring Harb Perspect Biol doi: 10.1101/cshperspect.a008912.

Segura I, Essmann CL, Weinges S, Acker-Palmer A. 2007. Grb4 and GIT1 transduce ephrin-B reverse signals modulating spine morphogenesis and synapse formation. Nat Neurosci 10: 301-310.

Seiradake E, Harlos K, Sutton G, Aricescu AR, Jones EY. 2010. An extracellular steric seeding mechanism for Eph-ephrin signaling platform assembly. Nat Struct Mol Biol 17: 398-402.

Senturk A, Pfennig S, Weiss A, Burk K, Acker-Palmer A. 2011. Ephrin Bs are essential components of the Reelin pathway to regulate neuronal migration. Nature 472: 356-360.

Shamah SM, Lin MZ, Goldberg JL, Estrach S, Sahin M, Hu L, Bazalakova M, Neve RL, Corfas G, Debant A, et al. 2001. EphA receptors regulate growth cone dynamics through the novel guanine nucleotide exchange factor ephexin. Cell 105: 233-244.

Sharma SV, Bell DW, Settleman J, Haber DA. 2007. Epidermal growth factor receptor mutations in lung cancer. Nat Rev Cancer 7: 169-181.

Shi W, Levine M. 2008. Ephrin signaling establishes asymmetric cell fates in an endomesoderm lineage of the Ciona embryo. Development 135: 931-940.

Shi L, Fu WY, Hung KW, Porchetta C, Hall C, Fu AK, Ip NY. 2007. $\alpha 2$-chimaerin interacts with EphA4 and regulates EphA4-dependent growth cone collapse. Proc Natl Acad Sci 104: 16347-16352.

Shiels A, Bennett TM, Knopf HL, Maraini G, Li A, Jiao X, Hejtmancik JF. 2008. The EPHA2 gene is associated with 
cataracts linked to chromosome 1p. Mol Vis 14: 2042 2055.

Shintani T, Ihara M, Sakuta H, Takahashi H, Watakabe I, Noda M. 2006. Eph receptors are negatively controlled by protein tyrosine phosphatase receptor type O. Nat Neurosci 9: 761-769.

Singla N, Erdjument-Bromage H, Himanen JP, Muir TW, Nikolov DB. 2011. A semisynthetic Eph receptor tyrosine kinase provides insight into ligand-induced kinase activation. Chem Biol 18: 361-371.

Skaggs BJ, Gorre ME, Ryvkin A, Burgess MR, Xie Y, Han Y, Komisopoulou E, Brown LM, Loo JA, Landaw EM, et al. 2006. Phosphorylation of the ATP-binding loop directs oncogenicity of drug-resistant BCR-ABL mutants. Proc Natl Acad Sci 103: 19466-19471.

Solanas G, Cortina C, Sevillano M, Batlle E. 2011. Cleavage of E-cadherin by ADAM10 mediates epithelial cell sorting downstream of EphB signalling. Nat Cell Biol 13: $1100-1107$.

Stahl S, Branca RM, Efazat G, Ruzzene M, Zhivotovsky B, Lewensohn R, Viktorsson K, Lehtio J. 2011. Phosphoproteomic profiling of NSCLC cells reveals that ephrin B3 regulates pro-survival signaling through Akt1-mediated phosphorylation of the EphA2 receptor. J Proteome Res 10: $2566-2578$.

Stein E, Lane AA, Cerretti DP, Schoecklmann HO, Schroff AD, Van Etten RL, Daniel TO. 1998. Eph receptors discriminate specific ligand oligomers to determine alternative signaling complexes, attachment, and assembly responses. Genes Dev 12: 667-678.

Tandon M, Vemula SV, Mittal SK. 2011. Emerging strategies for EphA2 receptor targeting for cancer therapeutics. Expert Opin Ther Targets 15: 31-51.

Tolias KF, Bikoff JB, Kane CG, Tolias CS, Hu L, Greenberg ME. 2007. The Racl guanine nucleotide exchange factor Tiam1 mediates EphB receptor-dependent dendritic spine development. Proc Natl Acad Sci 104: 7265-7270.

Truitt L, Freywald A. 2011. Dancing with the dead: Eph receptors and their kinase-null partners. Biochem Cell Biol 89: 115-129.

Udayakumar D, Zhang G, Ji Z, Njauw CN, Mroz P, Tsao H. 2011. EphA2 is a critical oncogene in melanoma. Oncogene 30: 4921-4929.

Van Hoecke A, Schoonaert L, Lemmens R, Timmers M, Staats KA, Laird AS, Peeters E, Philips T, Goris A, Dubois B, et al. 2012. EPHA4 is a disease modifier of amyotrophic lateral sclerosis in animal models and in humans. Nat Med 18: 1418-1422.

Vindis C, Cerretti DP, Daniel TO, Huynh-Do U. 2003. EphB1 recruits c-Src and p52Shc to activate MAPK/ ERK and promote chemotaxis. J Cell Biol 162: 661-671.

* Wagner MJ, Stacey MM, Liu BA, Pawson T. 2013. Molecular mechanisms of SH2- and PTB-domain containing proteins in receptor tyrosine kinase signaling. Cold Spring Harb Perspect Biol doi: 10.1101/cshperspect.a008987.

Wahl S, Barth H, Ciossek T, Aktories K, Mueller BK. 2000. Ephrin-A5 induces collapse of growth cones by activating Rho and Rho kinase. J Cell Biol 149: 263-270.

Wakayama Y, Miura K, Sabe H, Mochizuki N. 2011. EphrinA1-EphA2 signal induces compaction and polarization of Madin-Darby canine kidney cells by inactivating ezrin through negative regulation of RhoA. J Biol Chem 286: 44243-44253.

Walker-Daniels J, Riese DJ 2nd, Kinch MS. 2002. c-Cbldependent EphA2 protein degradation is induced by ligand binding. Mol Cancer Res 1: 79-87.

Wang Y, Nakayama M, Pitulescu ME, Schmidt TS, Bochenek ML, Sakakibara A, Adams S, Davy A, Deutsch U, Luthi U, et al. 2010. Ephrin-B2 controls VEGF-induced angiogenesis and lymphangiogenesis. Nature 465: 483-486.

Wegmeyer H, Egea J, Rabe N, Gezelius H, Filosa A, Enjin A, Varoqueaux F, Deininger K, Schnutgen F, Brose N, et al. 2007. EphA4-dependent axon guidance is mediated by the RacGAP $\alpha 2$-chimaerin. Neuron 55: 756-767.

Wei S, Xu G, Bridges LC, Williams P, White JM, DeSimone DW. 2010. ADAM13 induces cranial neural crest by cleaving class B ephrins and regulating Wnt signaling. Dev Cell 19: $345-352$.

Wimmer-Kleikamp SH, Janes PW, Squire A, Bastiaens PI, Lackmann M. 2004. Recruitment of Eph receptors into signaling clusters does not require ephrin contact. J Cell Biol 164: 661-666.

Wimmer-Kleikamp SH, Nievergall E, Gegenbauer K, Adikari S, Mansour M, Yeadon T, Boyd AW, Patani NR, Lackmann M. 2008. Elevated protein tyrosine phosphatase activity provokes Eph/ephrin-facilitated adhesion of pre-B leukemia cells. Blood 112: 721-732.

Wu C, Qiu R, Wang J, Zhang H, Murai K, Lu Q. 2009. ZHX2 Interacts with Ephrin-B and regulates neural progenitor maintenance in the developing cerebral cortex. J Neurosci 29: 7404-7412.

Wybenga-Groot LE, Baskin B, Ong SH, Tong JF, Pawson T, Sicheri F. 2001. Structural basis for autoinhibition of the EphB2 receptor tyrosine kinase by the unphosphorylated juxtamembrane region. Cell 106: 745-757.

Wykosky J, Gibo DM, Stanton C, Debinski W. 2005. EphA2 as a novel molecular marker and target in glioblastoma multiforme. Mol Cancer Res 3: 541-551.

Wykosky J, Palma E, Gibo DM, Ringler S, Turner CP, Debinski W. 2008. Soluble monomeric Ephrin-A1 is released from tumor cells and is a functional ligand for the EphA2 receptor. Oncogene 27: 7260-7273.

Xiao Z, Carrasco R, Kinneer K, Sabol D, Jallal B, Coats S, Tice DA. 2012. EphB4 promotes or suppresses Ras/ MEK/ERK pathway in a context-dependent manner: Implications for EphB4 as a cancer target. Cancer Biol Ther 13: 630-637.

Xu NJ, Henkemeyer M. 2009. Ephrin-B3 reverse signaling through Grb4 and cytoskeletal regulators mediates axon pruning. Nat Neurosci 12: 268-276.

Xu J, Litterst C, Georgakopoulos A, Zaganas I, Robakis NK. 2009. Peptide EphB2/CTF2 generated by the $\gamma$-secretase processing of EphB2 receptor promotes tyrosine phosphorylation and cell surface localization of $N$-methyl-Daspartate receptors. J Biol Chem 284: 27220-27228.

Yamaguchi Y, Pasquale EB. 2004. Eph receptors in the adult brain. Curr Opin Neurobiol 14: 288-296.

Yang NY, Fernandez C, Richter M, Xiao Z, Valencia F, Tice DA, Pasquale EB. 2011. Cross talk of the EphA2 receptor with a serine/threonine phosphatase suppresses the AktmTORC1 pathway in cancer cells. Cell Signal 23: $201-$ 212. 
E.M. Lisabeth et al.

Yin Y, Yamashita Y, Noda H, Okafuji T, Go MJ, Tanaka H. 2004. EphA receptor tyrosine kinases interact with coexpressed ephrin-A ligands in cis. Neurosci Res 48: 285296.

Yoo S, Kim Y, Noh H, Lee H, Park E, Park S. 2011. Endocytosis of EphA receptors is essential for the proper development of the retinocollicular topographic map. EMBO 30: $1593-1607$.

Yumoto N, Wakatsuki S, Kurisaki T, Hara Y, Osumi N, Frisen J, Sehara-Fujisawa A. 2008. Meltrin $\beta$ /ADAM19 interacting with EphA4 in developing neural cells participates in formation of the neuromuscular junction. PLoS ONE 3: e3322.

Zafeiriou DI, Pavlidou EL, Vargiami E. 2011. Diverse clinical and genetic aspects of craniofrontonasal syndrome. $\mathrm{Pe}$ diatr Neurol 44: 83-87.

Zelinski DP, Zantek ND, Stewart JC, Irizarry AR, Kinch MS. 2001. EphA2 overexpression causes tumorigenesis of mammary epithelial cells. Cancer Res 61: 2301-2306.

Zhang J, Yang PL, Gray NS. 2009a. Targeting cancer with small molecule kinase inhibitors. Nat Rev Cancer 9: 28-39.

Zhang T, Hua R, Xiao W, Burdon KP, Bhattacharya SS, Craig JE, Shang D, Zhao X, Mackey DA, Moore AT, et al. 2009b. Mutations of the EPHA2 receptor tyrosine kinase gene cause autosomal dominant congenital cataract. Hum Mutat 30: E603-611.

Zhuang G, Hunter S, Hwang Y, Chen J. 2007. Regulation of EphA2 receptor endocytosis by SHIP2 lipid phosphatase via phosphatidylinositol 3-Kinase-dependent Racl activation. J Biol Chem 282: 2683-2694.

Zhuang G, Song W, Amato K, Hwang Y, Lee K, Boothby M, Ye F, Guo Y, Shyr Y, Lin L, et al. 2012. Effects of cancerassociated EPHA3 mutations on lung cancer. J Natl Cancer Inst 104: 1182-1197.

Zimmer M, Palmer A, Kohler J, Klein R. 2003. EphB-ephrin-B bi-directional endocytosis terminates adhesion allowing contact mediated repulsion. Nat Cell Biol 5: 869_ 878.

Zisch AH, Pasquale EB. 1997. The Eph family: A multitude of receptors that mediate cell recognition signals. Cell Tissue Res 290: 217-226.

Zisch AH, Pazzagli C, Freeman AL, Schneller M, Hadman M, Smith JW, Ruoslahti E, Pasquale EB. 2000. Replacing two conserved tyrosines of the EphB2 receptor with glutamic acid prevents binding of $\mathrm{SH} 2$ domains without abrogating kinase activity and biological responses. Oncogene 19: 177-187.

Zwick E, Bange J, Ullrich A. 2002. Receptor tyrosine kinases as targets for anticancer drugs. Trends Mol Med 8: 17-23. 


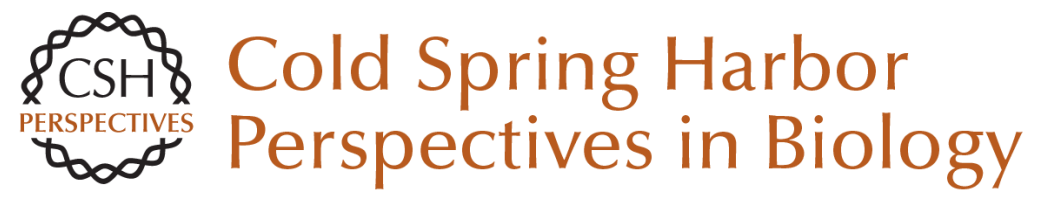

\section{Eph Receptor Signaling and Ephrins}

Erika M. Lisabeth, Giulia Falivelli and Elena B. Pasquale

Cold Spring Harb Perspect Biol 2013; doi: 10.1101/cshperspect.a009159

Subject Collection Signaling by Receptor Tyrosine Kinases

CSF-1 Receptor Signaling in Myeloid Cells

E. Richard Stanley and Violeta Chitu

The EGFR Family: Not So Prototypical Receptor

Tyrosine Kinases

Mark A. Lemmon, Joseph Schlessinger and Kathryn M. Ferguson

Tie2 and Eph Receptor Tyrosine Kinase Activation and Signaling

William A. Barton, Annamarie C. Dalton, Tom C.M. Seegar, et al.

The Spatiotemporal Organization of ErbB

Receptors: Insights from Microscopy

Christopher C. Valley, Keith A. Lidke and Diane S. Lidke

Insulin Receptor Signaling in Normal and Insulin-Resistant States

Jérémie Boucher, André Kleinridders and C. Ronald Kahn

Central Role of RET in Thyroid Cancer Massimo Santoro and Francesca Carlomagno

Receptor Tyrosine Kinase-Mediated Angiogenesis Michael Jeltsch, Veli-Matti Leppänen, Pipsa Saharinen, et al.

Biology of the TAM Receptors Greg Lemke
The Genesis of Tyrosine Phosphorylation Tony Hunter

Structure-Function Relationships of ErbB RTKs in the Plasma Membrane of Living Cells

Donna J. Arndt-Jovin, Michelle G. Botelho and Thomas M. Jovin

Receptor Tyrosine Kinases: Legacy of the First

Two Decades Joseph Schlessinger

The Role of Ryk and Ror Receptor Tyrosine Kinases in Wnt Signal Transduction Jennifer Green, Roel Nusse and Renée van Amerongen

Regulation of Receptor Tyrosine Kinase Ligand Processing Colin Adrain and Matthew Freeman

Molecular Mechanisms of SH2- and PTB-Domain-Containing Proteins in Receptor Tyrosine Kinase Signaling Melany J. Wagner, Melissa M. Stacey, Bernard A. Liu, et al.

Eph Receptor Signaling and Ephrins Erika M. Lisabeth, Giulia Falivelli and Elena B. Pasquale

Effects of Membrane Trafficking on Signaling by

Receptor Tyrosine Kinases Marta Miaczynska

For additional articles in this collection, see http://cshperspectives.cshlp.org/cgi/collection/

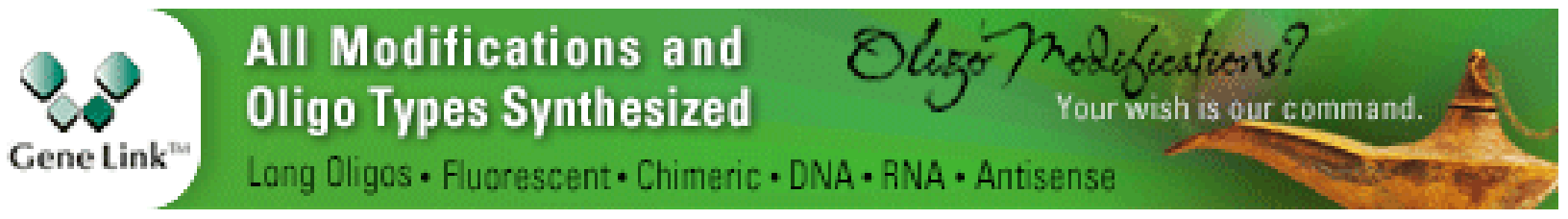


For additional articles in this collection, see http://cshperspectives.cshlp.org/cgi/collection/

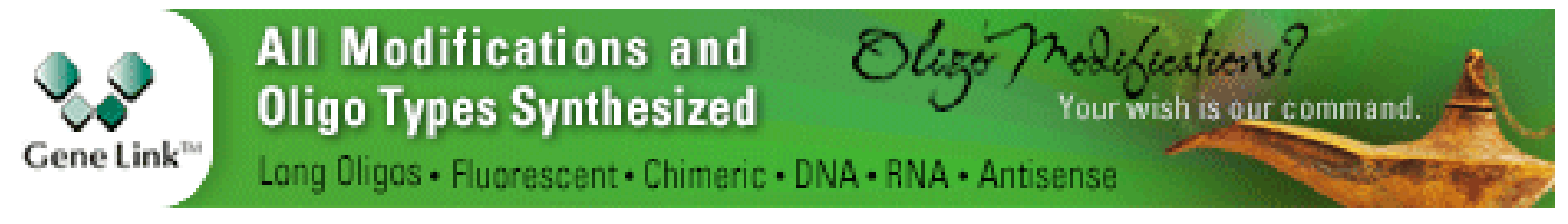

Copyright @ 2013 Cold Spring Harbor Laboratory Press; all rights reserved 